\title{
Spatial separation of foraging habitats among New Zealand fur seals
}

\author{
Brad Page $^{1,4, *}$, Jane McKenzie ${ }^{1}$, Michael D. Sumner ${ }^{2}$, Michael Coyne ${ }^{3}$, \\ Simon D. Goldsworthy ${ }^{1,4}$
}

\begin{abstract}
${ }^{1}$ Sea Mammal Ecology Group, Zoology Department, La Trobe University, Bundoora Campus, Victoria 3086, Australia ${ }^{2}$ Institute of Antarctic and Southern Ocean Studies, University of Tasmania, Private Bag 77, Hobart, Tasmania 7001, Australia ${ }^{3}$ Marine Geospatial Ecology Lab, Duke University, Durham, North Carolina 27708, USA
\end{abstract}

${ }^{4}$ Present address: South Australian Research and Development Institute (Aquatic Sciences), PO Box 120, Henley Beach, South Australia 5022, Australia

\begin{abstract}
We studied the foraging behaviour of lactating female, adult male and juvenile New Zealand (NZ) fur seals to compare and contrast their foraging strategies and assess the degree of spatial separation of their foraging habitats. Adult male fur seals are longer and heavier than lactating females, which are longer and heavier than juveniles. Trip duration was positively correlated with the distance travelled by all age/sex groups. Juveniles conducted longer trips and travelled further from the colony than males. Both juveniles and males conducted longer trips and travelled further than females, which made brief trips because they were provisioning pups. There were no seasonal differences in the behaviour of males, but females and juveniles foraged closer to the colony in summer when they were moulting and females had younger pups. Behavioural differences were recorded between lactating female, male and juvenile seals in the directional bearing from the colony, the distance travelled, the minimum size of the area that was potentially visited and the horizontal swim speed. Intra-specific foraging competition among these age/sex groups was minimal because lactating females typically used continental shelf waters and males utilised deeper waters over the shelf break, adjacent to female foraging grounds. Furthermore, juveniles used pelagic waters, up to $1000 \mathrm{~km}$ south of the habitats used by adults. Differences in the habitats used by females, males and juveniles were also apparent in the seafloor gradient, the SST and the surface chl a concentration, with females using regions with the highest chl a concentrations. Results from this study suggest that smaller seals cannot efficiently utilise prey in the same habitats as larger seals because smaller seals do not have the capacity to spend enough time underwater at the greater depths.
\end{abstract}

KEY WORDS: Arctocephalus · Sexual segregation · Sexual dimorphism • Foraging ecology • Resource partitioning

Resale or republication not permitted without written consent of the publisher

\section{INTRODUCTION}

Niche partitioning has been termed the ghost of competition past (Crowder 1986) because a common result of intense competition is that individuals alter their behaviour and/or the niche they utilise. The ways individuals utilise niches are also dictated by life history constraints, which are shaped by their strategies to maximise fitness.
Some species aggregate in great numbers to breed, dramatically increasing the potential for intra-specific competition for resources around colonies. Although coloniality confers selective benefits, such as enhanced mate-choice and defence against predators (reviewed in Andersson 1994), large aggregations of high-order consumers may deplete local food resources (Ashmole 1963, Birt et al. 1987). This may result in the separation of breeding and foraging 
habitats and increases the cost of commuting to provision dependent young, which remain at the central place (Orians \& Pearson 1979). In an attempt to reduce this cost, colonies of some terrestrial animals are located in different places from year to year, tracking their dynamic food resources (Brown et al. 1992). However, animals such as fur seals and sea lions utilise the marine environment to forage but must return to land to breed and nurse their dependent young. The energetic cost of commuting to foraging grounds is therefore a factor that may influence the location of colonies and affect the fitness of breeding seals, as has been demonstrated for seabirds (Hunt et al. 1986, reviewed in Gremillet et al. 2004).

In contrast, non-breeding seals are less constrained in where they can forage, so they would be expected to avoid proximal feeding grounds by conducting longer foraging trips to search out more profitable habitats. Recent studies on seals confirm that non-breeders typically spend longer at sea on each foraging trip and forage further afield than lactating females (Boyd et al. 2002, Sterling \& Ream 2004, Ream et al. 2005, Page et al. 2005a and references therein). Differences in the diet and diving behaviour of lactating female, male and juvenile New Zealand (NZ) fur seals Arctocephalus forsteri in southern Australia indicate that they utilise different prey and that lactating females typically utilise shallower habitats than males (Page et al. 2005a,b). Adult female NZ fur seals utilise more low energy prey such as squid, whereas adult males and juveniles use more energy-dense prey such as birds and fish (Page et al. 2005b). Little is known of the distribution of NZ fur seal prey in southern Australia. However, the dietary variation reflects differences in their metabolic requirements and physiological constraints, because lactating females also perform relatively brief foraging trips in order to nurse their dependent pups (Page et al. 2005b). In contrast, a greater diving capacity is thought to be necessary to access the prey that adult males require to maintain their relatively large body size, and juveniles are likely limited in their ability to utilise larger prey (Page et al. 2005a,b).

The distribution of different sized prey can influence the habitat utilised by predators because predator body size may affect the size of prey that can be efficiently captured, killed and consumed (e.g. Ashmole 1968). For air-breathing divers such as seals, body size is also related to oxygen storing capacity and diving ability, which determine how deeply prey can be accessed (Kooyman 1989). Furthermore, some large predators are thought to be less adept at capturing small prey, so these predators may specialise on larger, less-manoeuvrable and/or cryptic prey, which are typically benthic (e.g. Australian sea lions Neophoca cinerea, Gales \& Cheal 1992, Costa \& Gales 2003). Such predator/prey size relationships have been found among sympatric tern species and different demographic groups of fur seals (Ashmole 1968, Hulsman 1987, Page et al. 2005b).

Differences in the physical properties of water masses and bathymetric features can be associated with upwellings, frontal systems, eddies and thermoclines. Predators are thought to use these oceanographic features to improve their foraging success because they often correspond to elevated levels of primary, secondary and tertiary productivity (e.g. Georges et al. 2000, Ward et al. 2004). When these features alter the properties of surface waters, information on their location and intensity can be collected by satellite. Establishing links between predator foraging behaviour and oceanographic features can provide a greater understanding of the foraging habitats used by different predators. For example, changes in the sea surface temperature (SST) and the location of upwellings and frontal systems have been correlated with differences in fur seal foraging behaviour (e.g. Loughlin et al. 1999, Georges et al. 2000, Ream et al. 2005). In order for these relatively productive systems to be efficiently exploited by central-place foragers, they must be predictable in terms of their seasonality and their approximate location (Georges et al. 2000).

Although differences in the diving behaviour and diet of lactating female, adult male and juvenile NZ fur seals have been demonstrated (Page et al. 2005a,b), their foraging locations have not been documented. We used satellite telemetry to investigate where NZ fur seals foraged from a colony in southern Australia, in order to compare and contrast (1) their foraging locations, (2) their foraging behaviour and (3) the oceanographic features associated with the regions they utilised. Specifically, we predicted that constraints on the diving capacity of relatively small, juvenile NZ fur seals would compel them to utilise habitats where they could access prey in near surface waters. We hypothesised that the constraints on lactating females' trip durations would compel them to utilise regions that were relatively close to the colony. Although adult males have the diving capacity to utilise the same habitats as females and juveniles, males have a larger body size and therefore they have higher energy requirements, which may require that they exploit niches differently to smaller seals. Accordingly, we predicted that the foraging habitats used by males would not be utilised by females or juveniles, either because they were located too far from the colony or because within these habitats the prey were too deep. 


\section{MATERIALS AND METHODS}

Study site. The study was conducted between July 2000 and March 2003 at the Cape Gantheaume Conservation Park on the south coast of Kangaroo Island, South Australia ( $36^{\circ} 04^{\prime} \mathrm{S}, 137^{\circ} 28^{\prime}$ E) (Fig. 1A). The NZ fur seal population at Cape Gantheaume has increased by approximately $16 \%$ per annum since monitoring began in 1987 and currently numbers about 8900 ind. (Goldsworthy et al. 2003). The continental shelf to the south of Cape Gantheaume is typically 60 to $90 \mathrm{~m}$ deep, with the nearest continental shelf edge $(200 \mathrm{~m}$ depth contour) and pelagic waters (greater than $2000 \mathrm{~m}$ depth) being located 70 and $85 \mathrm{~km}$ south of Cape Gantheaume, respectively (Fig. 1A).

Capture and restraint. In 2000, all juveniles and lactating females were captured using a hoop-net and given Midazolam (intramuscular: 0.15 to $0.40 \mathrm{mg} \mathrm{kg}^{-1}$, Hypnovel, Roche Products) to reduce capture stress and facilitate anaesthetic induction. Anaesthesia was induced and maintained using Isoflurane (Veterinary Companies of Australia), administered via a portable gas anaesthetic machine (Komesaroff Small Animal Anaesthetic Machine, Medical Developments Australia). To reduce capture stress in 2001 to 2002, lactating females were given Zoletil (intramuscular: $\sim 2.0 \mathrm{mg}$ $\mathrm{kg}^{-1}$, Virbac) prior to capture-administered using 0.5 cc barbless darts (Pneu-Dart), fired from a $\mathrm{CO}_{2}$ powered tranquilliser gun (Taipan 2000, Tranquil Arms Company). Anaesthetised females were then captured using a hoop-net and restrained by 1 to 2 people because initial restraint stimulated a flight response in all but a few deeply-anaesthetised seals. No Midazolam was used on seals that were given Zoletil, but in most cases anaesthesia had to be maintained using Isoflurane. Adult males, which appeared to be large enough to defend breeding territories during the breeding season, were lightly anaesthetised using Zoletil (intramuscular: $1.5 \mathrm{mg} \mathrm{kg}^{-1}, 1.0 \mathrm{cc}$ barbless darts), captured using a hoop-net, restrained by 2 to 4 people and deeply anaesthetised with Isoflurane using the equipment and methods outlined above. All of our research procedures were approved by the La Trobe University Animal Ethics Committee and the South Australian Department for Environment and Heritage Animal Ethics Committee.

Data collection. Anaesthetised seals were weighed with a spring balance $(50 \pm 0.1 \mathrm{~kg}$ or $200 \pm 1.0 \mathrm{~kg}$, Salter) and their body length (nose to tail) was measured $( \pm 1 \mathrm{~cm})$. Individually-numbered plastic tags (Supertags, Dalton) were applied to the trailing edge of each foreflipper. To determine the age of seals a postcanine tooth was removed using dental elevators (females: $3 \mathrm{~mm}$, males: $5 \mathrm{~mm}$ ). To provide short-term pain relief, a local anaesthetic $(0.7 \mathrm{ml}$, Lignocaine,
AustraZeneca) was injected in the gum beside the post-canine. Ages were estimated by counting growth layer groups in the cementum of decalcified and stained longitudinal sections of post canines, using methods adapted from Stewart et al. (1996). The aging technique was validated on post-canine teeth that were collected from 22 known-age NZ fur seals. Age was correctly assigned to 17 ( $77 \%$ ) of the known-aged individuals and underestimated by 1 yr for the other 5 $(23 \%)$ individuals (J. McKenzie unpubl. data).

Satellite transmitters (KiwiSat 101, Sirtrack) were deployed on 27 females, 21 males and 6 juveniles. Time depth recorders (TDRs, Mk7, Wildlife Computers) were concurrently deployed on 27 females and 13 males (Page et al. 2005a), but not on any juveniles. Transmitters were glued to the fur on the dorsal midline, using a flexible-setting epoxy (Araldite 2017, Vantico). To reduce power consumption, transmitters incorporated a saltwater switch, which turned the transmitter off when it was underwater and transmitters that were deployed on juveniles were programmed to transmit every second day.

Data analyses. To avoid potential biases owing to the different number of foraging trips recorded, data from the second and subsequent foraging trips by the same seal were not used in this study. Foraging trips ended when seals hauled-out on land, which was not always at Cape Gantheaume. If a satellite transmitter failed before a seal returned to land (juveniles $\mathrm{n}=2$ ), the remaining trip duration was estimated based on the average horizontal speed recorded and the remaining straight-line distance to Cape Gantheaume, where both seals appeared to be heading.

Satellite location data were obtained through Service Argos. The location-class $B$ and $Z$ positions were omitted due to the magnitude of their error (Sterling \& Ream 2004). The R statistical software (version 2.0.1, R Development Core Team 2004) and the timeTrack package (version 1.0-9, M. Sumner) were used to apply the filter described by McConnell et al. (1992), based on a maximum horizontal speed of $2 \mathrm{~m} \mathrm{~s}^{-1}$.

To determine the number of different $5 \mathrm{~km} \times 5 \mathrm{~km}$ $\left(25 \mathrm{~km}^{2}\right)$ grid cells entered by each seal and the proportion of time that they spent in each cell, we assumed a constant horizontal speed between the filtered locations and interpolated a new position for each minute (of time) along the satellite track, using the $\mathrm{R}$ statistical software and the timeTrack package. The number of original and interpolated positions, which were located within $25 \mathrm{~km}^{2}$ cells of a predetermined grid, were then summed and assigned to a central node. Cells that bounded Cape Gantheaume were entered by all seals when commuting near the colony and as a result these cells had relatively high timespent values. NZ fur seals do not typically forage in 
waters adjacent to Cape Gantheaume (Page et al. $2005 a, b)$, so the time-spent-in-area values were logtransformed to improve the clarity of the time spent in area figures. To ensure that different foraging trip durations or the number of seals tracked in different seasons did not bias comparisons, the logged amount of time spent in each cell was converted to a proportion of the total time-spent values for each individual, season and/or age/sex group being compared. To improve the clarity of the time spent in area figures, the proportional values of logged time-spent-in-area were plotted using the triangulation with smoothing function in VerticalMapper (version 2.5) (MapInfo Corporation) and plotted using MapInfo (version 6.0).

Spatial overlap in foraging area was quantified by determining the proportion of time spent in $25 \mathrm{~km}^{2}$ grid cells, which were used by more than 1 age/sex group. To examine the influence of putative traveling behaviour (i.e. low time spent in area values) on the degree of spatial overlap, we also compared proportion of time that more than 1 age/sex group spent foraging in the same area based on the minimum number of cells that constituted 50,80,90 and $99 \%$ of the time spent at sea for each age/sex group. This was done using data that had not been transformed.

We calculated several parameters to summarise the foraging behaviour of each seal and to describe differences in the physical and biological habitats they utilised. To describe the features and behaviours in proportion to the amount of time spent in each area, the parameters were extracted at 15 min (time) intervals along each interpolated satellite track (except for parameters that described maximums or totals). Behavioural parameters were calculated to describe (1) the total distance travelled (the sum of distances between locations), (2) the maximum straight-line distance from Cape Gantheaume to the distal point reached, (3) the bearing from Cape Gantheaume to each interpolated position, (4) the horizontal travel speed (the distance between consecutive locations, divided by the duration [15 min]), (5) the total number of grid cells entered and (6) the minimum number of grid cells entered that constituted $50 \%$ of the foraging trip duration. Parameters 5 and 6 were calculated to estimate the minimum size of the potential area visited (PAV) by each seal. Oceanographic parameters were calculated to describe (1) the mean and (2) the median bathymetry, (3) the mean bathymetric gradient (change in depth in metres for each horizontal kilometre), (4) the median directional bearing of the bathymetric gradient (degrees), (5) the sea surface temperature (SST) and (6) the surface chl a concentration. Bathymetry values were obtained from the GEBCO 1-Minute World Bathymetry Grid. SST data were obtained from the AVHRR sensor - part of the Multi-
Channel Sea Surface Temperature dataset, compiled by the US Naval Oceanographic Office and distributed by the Global Ocean Data Assimilation Experiment. The surface chl a data between July 2000 and July 2002 were obtained from SEAWiFS, which has $9 \mathrm{~km}^{2}$ spatial resolution. After July 2002, the chlorophyll data came from the Moderate Resolution Imaging Spectroradiometer (MODIS) weekly-average database, which has $4 \mathrm{~km}^{2}$ spatial resolution. If no chlorophyll data were available the monthly average was used. The bathymetry, SST and chlorophyll values for each location were interpolated as functions of their distance from the nearest nodes and assigned to each $15 \mathrm{~min}$ interval.

Semi-strong hybrid multi-dimensional scaling (MDS) was employed for multivariate analyses of the behavioural and foraging habitat parameters (see Tables 1 \& 2), to compare among individuals, seasons and sexes, using the PATN Analysis Package (Division of Wildlife and Ecology, CSIRO). The Bray and Curtis association measure was used for the analysis, because it is an effective method for analysing multivariate ecological data (Beals 1984). A scree plot was used to determine the number of dimensions to use in MDS analyses. Principal axes correlation was used to determine the most influential variables in MDS analyses. Principal axes correlation takes the variables (behavioural or foraging habitat parameters) and finds the location of the best-fitted vector in the ordination space. Variables with significant correlation coefficients (r) were included on the end of each axis (see Figs. 2 \& 3). Stress values were calculated to give an indication of how well the data were represented during ordination. The stress in an MDS is a measure of how distorted (or scattered) the data are, after being confined to a limited number of vectors. The lower the stress value, the better the MDS representation of the data. Generally, stress values less than 0.10 are regarded as being unlikely to result in misinterpretation of the data (Schiffman et al. 1981).

A forced-entry method of discriminant function analyses (DFA) was also used to compare differences among the behavioural parameters of females, males and juveniles (version 11, SPSS). DFA indicates variation by showing the proportion of individuals that are correctly assigned back to their original groups based on analysis of the behavioural parameters. Crossvalidation was performed to verify the precision of the groupings. When interpreting the results of a DFA, a good classification is regarded as one that correctly assigns a greater proportion of individuals than would be expected to occur by chance alone.

The following parameters were power-transformed to equate variances: trip duration, total distance travelled, maximum distance from the colony, the number 
of grid cells entered (the sizes of the minimum potential area visited during 50 and $100 \%$ of the trip) and the directional bearing of the bathymetric gradient. These transformations did not result in the data being normally distributed for all age/sex groups, so MannWhitney $U$-tests were used for most analyses, for which $Z$ approximations are reported. Preliminary analyses indicated that there were no significant differences in the behaviour of male and female juveniles, so the data from both sexes were pooled. Similarly, there were too few data to examine inter-annual trends, so data from all years were pooled to examine seasonal patterns. Means are presented as $\pm \mathrm{SD}$ and all statistical tests are 2-tailed, unless stated, with the $\alpha$ level of statistical significance set at 0.05 . Austral seasons are referred to throughout this paper: summer (December to February), autumn (March to May), winter (June to August) and spring (September to November).

\section{RESULTS}

In total, 3157 unfiltered locations (classes $A, 0,1,2,3$; the most accurate satellite positions) were available from the first foraging trips made by 25 female (640 locations), 21 male (1825 locations) and 6 juvenile (692 locations) NZ fur seals (Table 1). Two of the transmitters on females did not produce any locations. The filter removed 313 locations. After filtering, the average number of locations per day at sea was as follows: females $5.9 \pm 4.3$; males $7.9 \pm 3.8$; and juveniles $2.7 \pm$ 0.8 (Table 1).

Lactating females were significantly shorter and lighter than males (length: $t=24.02, \mathrm{p}<0.001$; mass: $t=19.32, \mathrm{p}<0.001$ ) (Table 1). Juveniles were significantly shorter and lighter than both females (length: $t=$ 10.52, $\mathrm{p}<0.001$; mass: $t=13.34, \mathrm{p}<0.001$ ) and males (length: $t=24.62, \mathrm{p}<0.001$; mass: $t=13.35, \mathrm{p}<0.001$ ) (Table 1). Ages ranged from 6 to $17 \mathrm{yr}$ for females (average $9.3 \pm 2.5$ ), 10 to $18 \mathrm{yr}$ for males (average $12.9 \pm$ 1.8) and 2 to 5 for juveniles (average $3.5 \pm 1.2$ ) (Table 1). All of the adult males studied defended breeding territories in at least one of the following breeding seasons (2001-02 to 2004-05), indicating that they were physically and socially mature (J. McKenzie unpubl. data).

\section{Foraging trip duration}

Overall, males made significantly longer foraging trips than females $(Z=3.18, \mathrm{p}=0.001)$ and juveniles made significantly longer trips than both females $(Z=$ $3.75, \mathrm{p}<0.001)$ and males $(Z=3.56, \mathrm{p}<0.001)$
(Table 1). In autumn and winter, females made significantly longer foraging trips than females in summer $(Z$ $>2.12, \mathrm{p}<0.034$ in both cases), but there were no other significant seasonal differences in trip duration for females, males or juveniles $(Z<1.53, \mathrm{p}>0.05$ in all cases) (Table 1). Foraging trip duration was significantly and positively correlated with total distance travelled (females: $\mathrm{r}=0.913, \mathrm{p}<0.001$; males: $\mathrm{r}=0.745$, $p<0.001$; juveniles: $r=0.886, p=0.019$ ). For females and males, foraging trip duration was significantly and positively correlated with the maximum distance from the colony (females: $r=0.922, p<0.001$; males: $r=$ $0.685, p=0.001)$. Neither age, length nor mass were significantly correlated with foraging trip duration (seasonally nor overall) for females, males and juveniles ( $p>0.05$ in all cases).

\section{Summary of foraging behaviour}

Most females travelled within an arc from east to south of Cape Gantheaume (median bearing $128^{\circ}$ ) and travelled total distances between 37 and $642 \mathrm{~km}$ (average $259.8 \pm 187.7 \mathrm{~km}$ ) (Table 1, Fig. 1A). Males travelled total distances between 92 and $1154 \mathrm{~km}$ (average $471.2 \pm 247.2 \mathrm{~km}$ ) within the arc from southeast to south of the colony (median bearing $146^{\circ}$ ) (Table 1 , Fig. 1B). Juveniles typically travelled between southeast and south of Cape Gantheaume (median bearing $\left.163^{\circ}\right)$, traveling total distances between 688 and $>2690 \mathrm{~km}$ (average for completed foraging trips $1464.5 \pm 730.2 \mathrm{~km}$ ) (Table 1, Fig. 1C). Overall, the bearings and total distances travelled by females, males and juveniles differed significantly in all age/sex group comparisons $(Z>2.24, \mathrm{p}<0.025$ in all cases) (Table 1).

\section{Swim speed and maximum distance from the colony}

The maximum distance reached from Cape Gantheaume differed significantly between females (average $259.8 \pm 187.7 \mathrm{~km})$, males $(471.2 \pm 247.2 \mathrm{~km})$ and juveniles $(1701.3 \pm 748.7 \mathrm{~km})(Z>2.72, \mathrm{p}<0.006$ in all cases) (Table 1). Overall, the average horizontal speed recorded for females $\left(0.77 \pm 0.36 \mathrm{~m} \mathrm{~s}^{-1}\right)$, males $(0.88 \pm$ $\left.0.24 \mathrm{~m} \mathrm{~s}^{-1}\right)$ and juveniles $\left(0.65 \pm 0.24 \mathrm{~m} \mathrm{~s}^{-1}\right)$ did not differ significantly $(F=1.49, \mathrm{p}=0.236)$ (Table 1$)$. The proportion of maximum distance from Cape Gantheaume was calculated at $15 \mathrm{~min}$ intervals to examine the relationship between the distance from the colony and average horizontal speed. The proportion of maximum distance was negatively correlated with average horizontal speed in both the first half (females: $r=0.213$, $\mathrm{p}=0.001$; males: $\mathrm{r}=0.321, \mathrm{p}=0.001$; juveniles: $\mathrm{r}=$ 


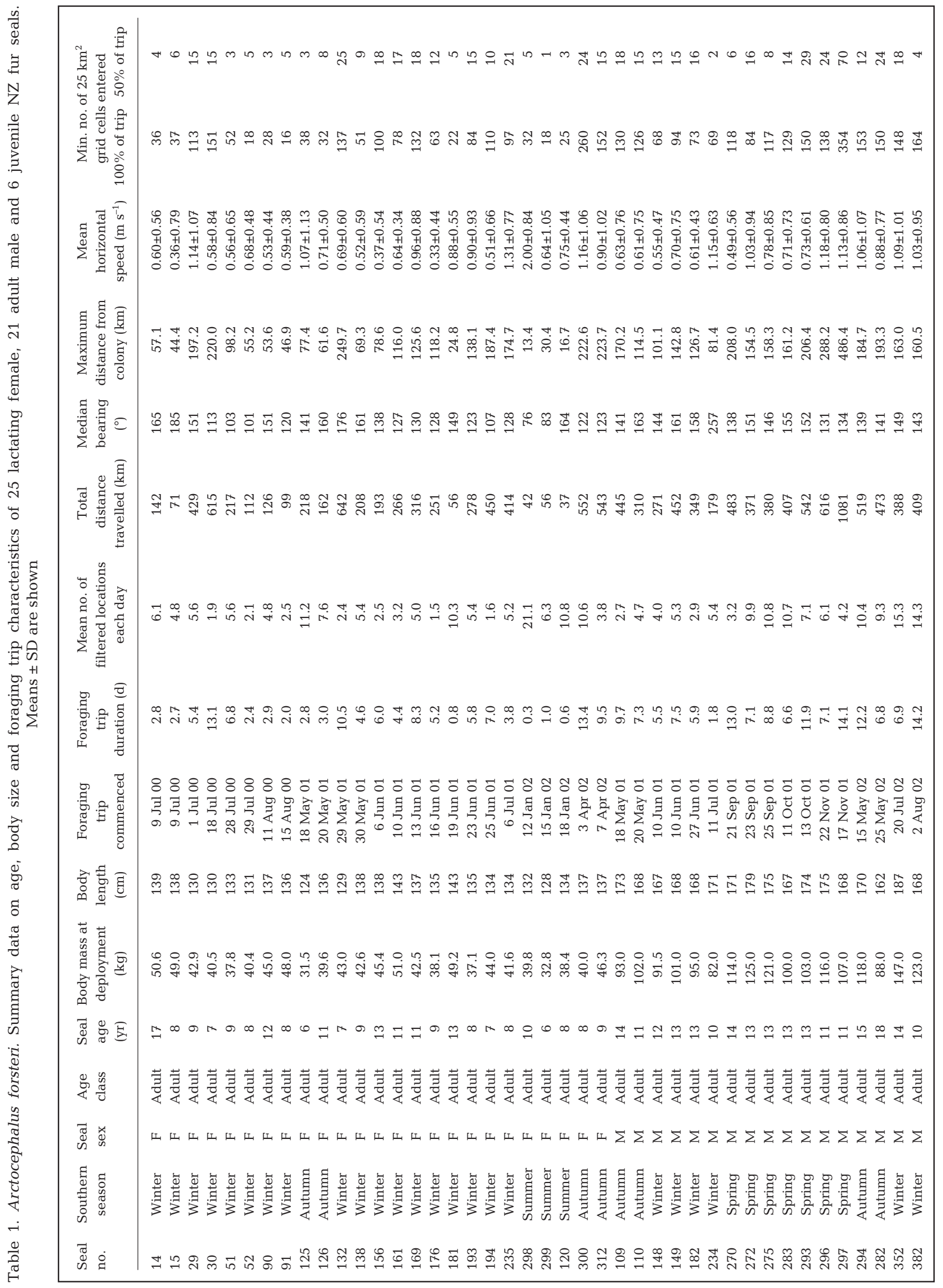




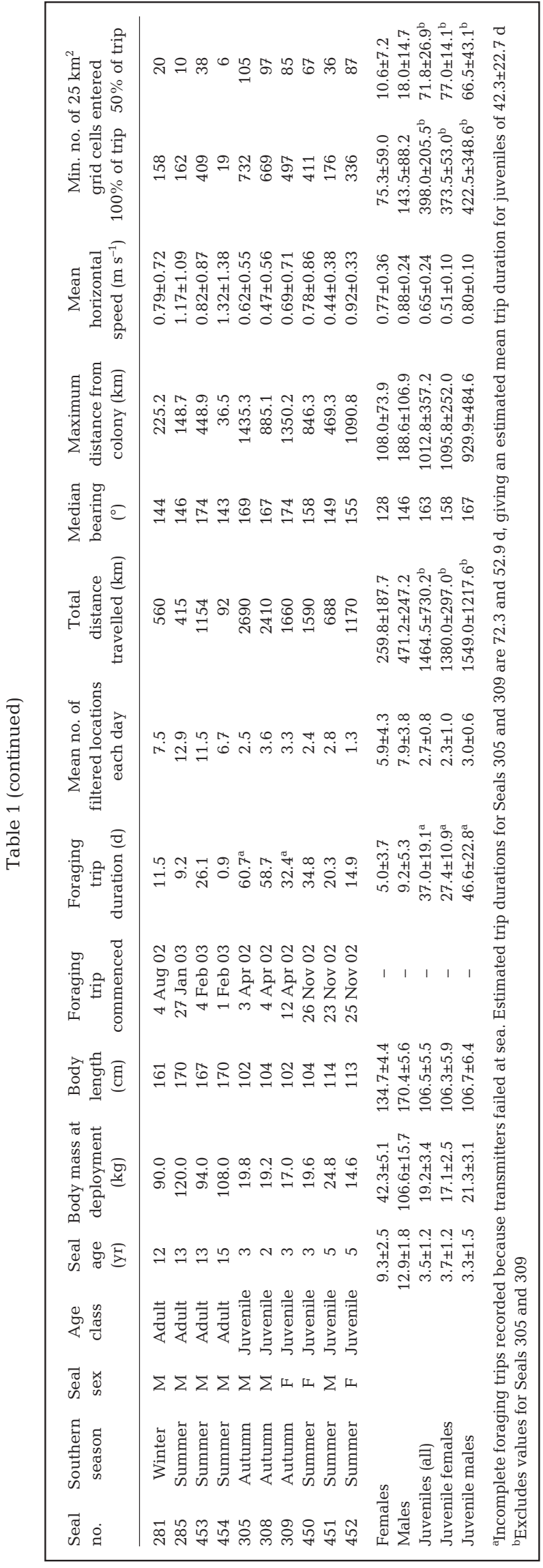

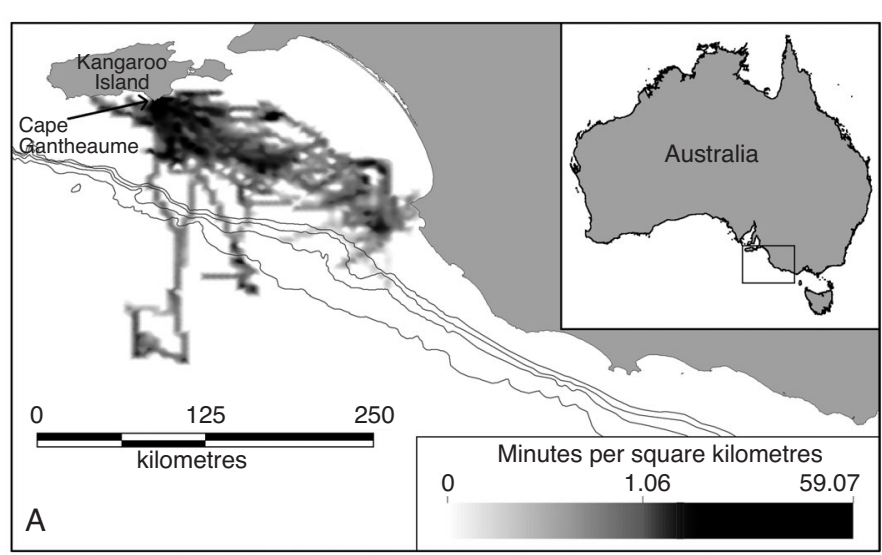
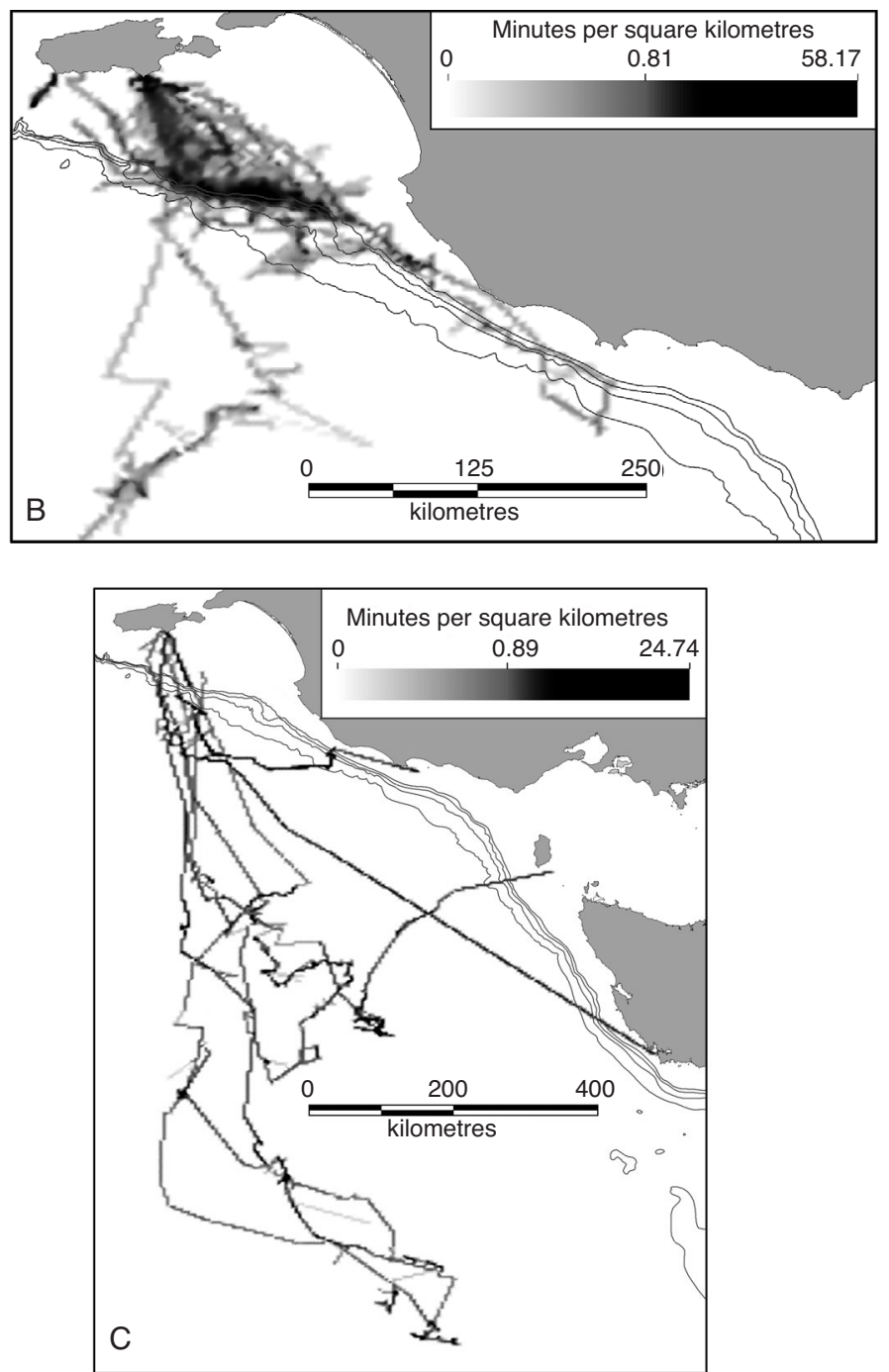

Fig. 1. Arctocephalus forsteri. Time spent in $25 \mathrm{~km}^{2}$ cells by (A) lactating female $(\mathrm{n}=25)$, (B) adult male $(\mathrm{n}=21)$ and (C) juvenile $(n=6) \mathrm{NZ}$ fur seals, which were satellite-tracked from Cape Gantheaume. Location of Cape Gantheaume in relation to the continental shelf, shelf break $(200,500,1000$ and $2000 \mathrm{~m}$ depth contours) and pelagic waters (south of the shelf break) is shown 


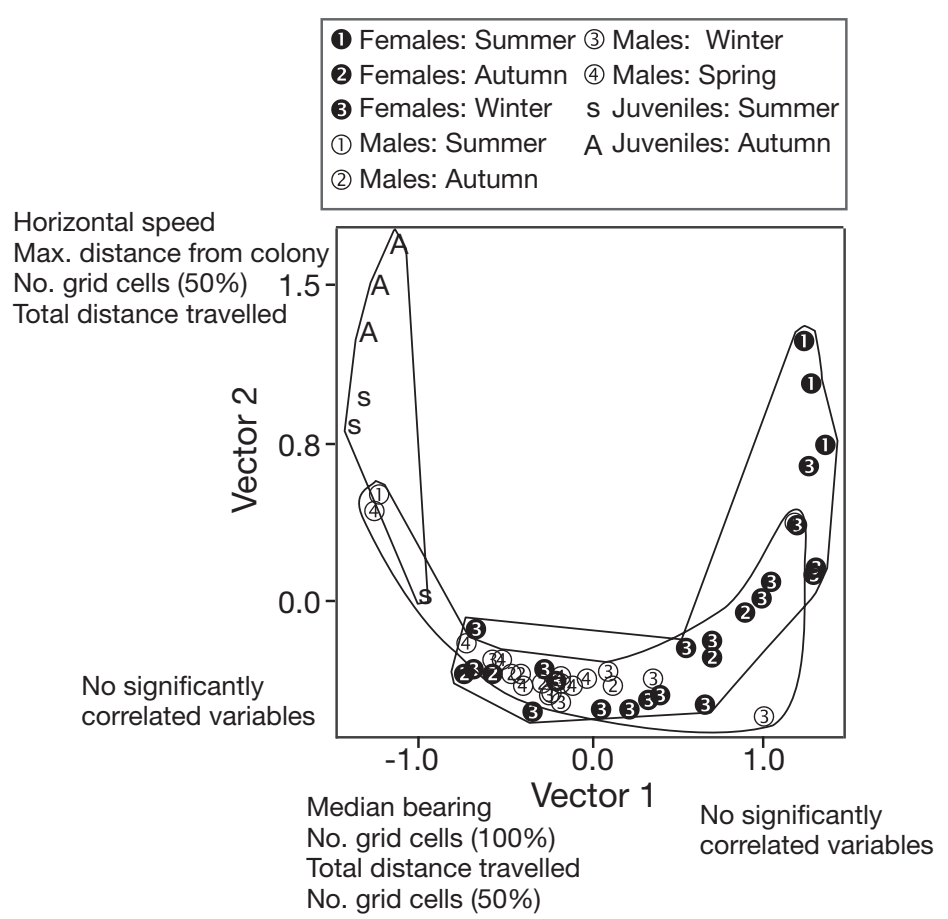

Fig. 2. Arctocephalus forsteri. Inter-individual, inter-seasonal and intra-seasonal variation in parameters that described behaviour of lactating female $(\bullet, n=25)$, adult male $(\mathrm{O}, \mathrm{n}=21)$ and juvenile $(\mathrm{s} / \mathrm{A}, \mathrm{n}=$ 6) NZ fur seals. Each individual's single foraging trip is represented by a single point and seasons are represented by different numbers. A polygon encloses each age/sex group. Up to 4 variables (behavioural parameters) that had significant correlation coefficients are shown on the ends of each axis; 2 -dimensional stress $=0.058$

0.286, $p=0.001$ ) and second half (females: $r=0.395$, $\mathrm{p}=0.001$; males: $\mathrm{r}=0.387, \mathrm{p}=0.001$; juveniles: $\mathrm{r}=$ $0.354, p=0.001$ ) of foraging trips, indicating that seals travelled more rapidly when they were close to the colony compared with when they were close to their maximum distance.

\section{Demographic differences: foraging behaviour}

The first MDS analysis shows the similarity of individuals' foraging behaviour parameters (Fig. 2). Juveniles separated from males and females based on differences in the significantly-correlated variables that summarised the horizontal speed, the median bearing, the maximum distance from the colony, the minimum size of the PAV in 50 and $100 \%$ of the trip and the total distance travelled (Fig. 2). Some females, particularly those from summer, separated from males based on differences in horizontal speed, maximum distance from the colony, the minimum size of the PAV in $50 \%$ of the trip and total distance travelled (Fig. 2). Other females and males overlapped as a result of similarities in the parameters that summarised the median bearing, the minimum size of the PAV in 50 and $100 \%$ of the trip and the total distance travelled (Fig. 2). The forced-entry DFA based on the behavioural variables also indicated differences in the behaviour of the age/sex groups: it assigned 72.0, 81.0 and $83.3 \%$ (64.0, 71.4 and $66.7 \%$ cross-validated) of females, males and juveniles back to the correct category.

The MDS analysis of behavioural parameters indicated seasonal differences for juveniles (summer versus autumn) and females (summer versus other seasons), but not for males (Fig. 2). In summer, differences in the horizontal speed, maximum distance from the colony, minimum size of the PAV in $50 \%$ of the trip and total distance travelled by juveniles and females were responsible for the seasonal differences (Fig. 2). The maximum and total distances recorded for females in autumn and winter and the total distance travelled by juveniles in autumn were significantly greater than the distances recorded in summer $(Z>1.96, p<0.025$ in all cases) (Table 1). The PAV during their entire trips for females and juveniles in autumn and the minimum size of the PAV in $50 \%$ of the trip by females in winter were all significantly greater than the minimum size of the PAV in summer $(Z>1.96, \mathrm{p}<0.05$ in all cases $)$

(Table 1). The bearing for juveniles in autumn was significantly greater than in summer $(Z=1.96, \mathrm{p}$ $=0.050)$ (Table 1).

\section{Demographic differences: oceanography}

The second MDS analysed the oceanographic parameters and shows the similarity of individuals' oceanographic parameters (Fig. 3). The multivariate analysis of oceanographic data grouped individuals into 3 clusters: (1) continental shelf (23 females and 2 males), (2) pelagic waters (6 juveniles, 1 male and 2 females) and (3) shelf break (18 males). Juveniles separated from most males and females based on differences in all of the significantly correlated variables (Fig. 3). Females typically separated from males based on differences in mean chlorophyll concentration, SST, median bathymetric gradient and mean and median bathymetry (Fig. 3). The DFA based on oceanographic variables confirmed differences between the age/sex groups by assigning 92.0, 85.7 and 100.0\% (84.0, 81.0 and $100.0 \%$ cross-validated) of females, males and juveniles correctly. 

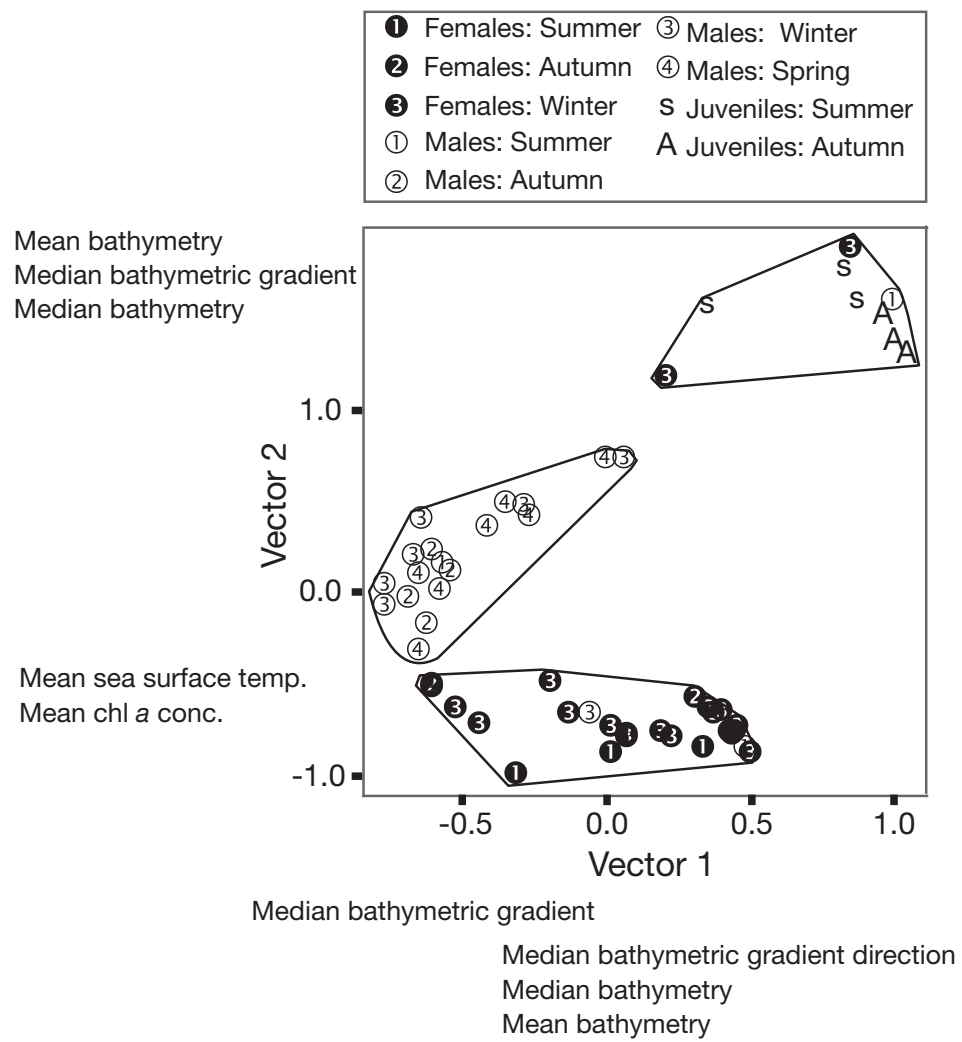

Fig. 3. Arctocephalus forsteri. Inter-individual, inter-seasonal and intraseasonal variation in parameters that describe physical and biological oceanography in the habitats used by lactating female $(\bullet, n=25)$, adult male $(\mathrm{O}, \mathrm{n}=21)$ and juvenile ( $/ \mathrm{A}, \mathrm{n}=6) \mathrm{NZ}$ fur seals. Each individual's single foraging trip is represented by a single point and seasons are represented by different numbers. A polygon encloses groups that used pelagic waters (top right polygon: 6 juveniles, 2 lactating females, 1 adult male), shelf break waters (middle polygon: 18 adult males) and continental shelf waters (bottom polygon: 23 females, 2 adult males). Up to 3 variables (oceanographic parameters) that had significant correlation coefficients are shown on the ends of each axis; 2-dimensional stress $=0.070$

On average, juveniles foraged over waters that were significantly deeper than those used by males (median depths: 4578.9 and $132.7 \mathrm{~m}$, mean depths: $4036.8 \pm$ $809.3 \mathrm{~m}$ and $467.3 \pm 975.9 \mathrm{~m}$, respectively; Table 2, Fig. 4$)(Z=3.30, p=0.001$ in both cases). Both juveniles and males foraged over significantly deeper habitats than females (median depth: $41.2 \mathrm{~m}$, mean depth:

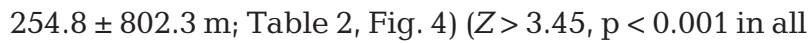
cases). Although juveniles could not have foraged near the benthos, the bathymetric gradient recorded for juveniles $\left(22 \pm 13 \mathrm{~m} \mathrm{~km}^{-1}\right)$ was significantly steeper than that recorded for females $\left(4 \pm 12 \mathrm{~m} \mathrm{~km}^{-1}\right)(Z=3.25, \mathrm{p}=$ $0.001)$, but the difference was not significant between males $\left(25 \pm 15 \mathrm{~m} \mathrm{~km}^{-1}\right)$ and juveniles $(Z=0.32$, $p=0.345$ ) (Table 2 ). Females typically utilised waters over the continental shelf and males used habitats on the shelf break (Fig. 1A,B), which was reflected by the significant difference in the bathymetric gradient $(Z=4.89, \mathrm{p}<0.001)$ (Table 2 ).

Seasonal comparisons of the SST and surface chl a concentration were made between the continental shelf, shelf break and pelagic habitats, which were identified in the MDS analysis (Fig. 3). The lactating females $(\mathrm{n}=2)$ and adult males $(n=2)$ that did not feed over the continental shelf and shelf break, respectively, were excluded from this analysis because there were too few individuals to statistically compare these groups. In summer and autumn, the shelf waters used by females had higher SST than the pelagic waters used by juveniles, but the chl a concentrations were only higher over the shelf in autumn $(Z>1.96, \mathrm{p}<0.050$ in all cases $)$ (Table 2). Autumn SST was higher in shelf break waters used by males than in waters used by juveniles $(Z=2.12, \mathrm{p}=0.034)$, but chl a concentrations did not differ significantly ( $Z=0.90, p=0.368$ ) (Table 2 ). In autumn and winter, chl a concentrations were higher in the shelf waters used by females than in the shelf break waters used by males $(Z>2.34, \mathrm{p}<0.019$ in both cases), but the SST did not differ significantly $(Z<$ $0.85, \mathrm{p}>0.40$ ) (Table 2).

In the shelf regions utilised by females, SST was significantly higher during summer than it was during autumn and winter $(Z>$ $2.14, \mathrm{p}<0.032$ in both cases), but the chl $a$ concentration did not differ significantly $(Z<$ $1.68, \mathrm{p}>0.867$ in both cases) (Table 2). Where females foraged, the SST and chl a concentration were significantly higher in autumn than winter $(Z=2.75, \mathrm{p}=0.006)$

(Table 2). Over the shelf break, where males foraged, SST was significantly higher in autumn than it was during winter and spring $(Z>2.13, \mathrm{p}<0.033$ in both cases) (Table 2). The SST in winter and spring and chl a concentrations in autumn, winter and spring did not vary significantly where males foraged $(Z<1.235$, $p>0.85$ in all cases) (Table 2). Neither SST nor chl a concentrations were significantly different in the pelagic waters used by juveniles in summer and autumn $(Z<1.53, \mathrm{p}>0.127$ in both cases) (Table 2$)$.

\section{Habitat separation among male, female and juvenile NZ fur seals}

The degree of spatial overlap between each of the age/sex groups is presented in Fig. 5. Each point depicts the proportion of time spent in grid cells that 


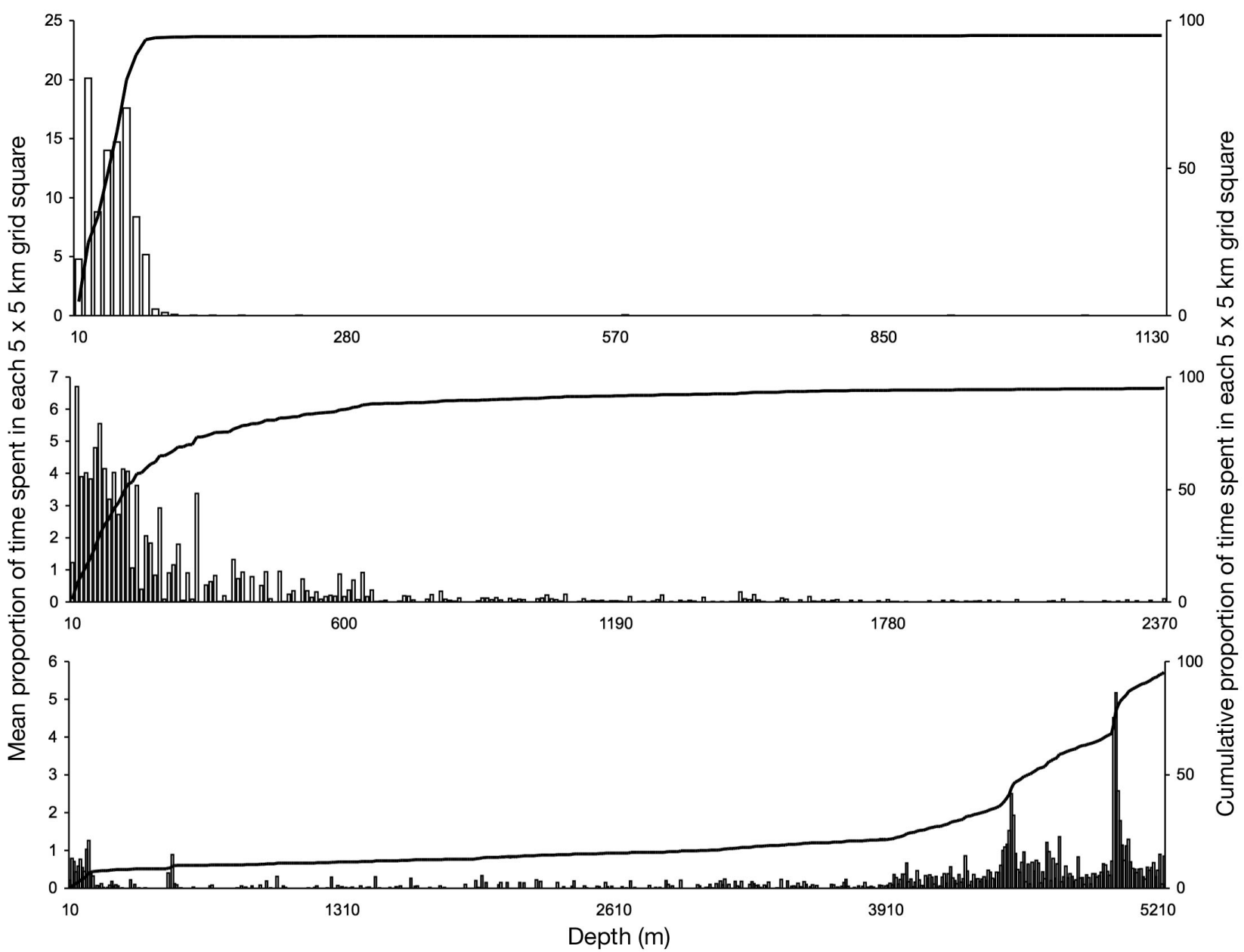

Fig. 4. Arctocephalus forsteri. Relationship between the depth of each $25 \mathrm{~km}^{2}$ cell (note different scales for each plot) used by seals and mean proportion of time spent in those cells by lactating females (top, $\mathrm{n}=25$ ), adult males (middle, $\mathrm{n}=21$ ) and juveniles (bottom, $\mathrm{n}=6$ ). Cumulative proportion of time spent over each depth is represented for each age/sex group ( $y$-axis), indicating minimum number of cells required to constitute $95 \%$ of time spent at sea

were entered by more than 1 age/sex group (Fig. 5). The $45^{\circ}$ line indicates the position of a hypothetical 1:1 level of overlap between 2 groups (Fig. 5). In all comparisons the age/sex group on the $x$-axis spent relatively more time foraging in the region of overlap compared with the group on the $y$-axis because all the curves were plotted below the $45^{\circ}$ line (Fig. 5).

The degree of overlap between males and females was greater than between juveniles and either adult group (Fig. 5). Females utilised a relatively small area, much of which was used by males and juveniles (Figs. 1 \& 5). Males used a larger area than females (Fig. 1A,B), and males spent most of their time foraging outside the areas used by females (Figs. 5 \& 6B). Trendlines that depicted the degree of overlap between males and females were relatively long, indicating a high level of overlap based on the PAV during $100 \%$ of cells visited and lower levels based on the PAV in $50 \%$ of time spent at sea (Fig. 5). Based on the
PAV during the entire trip (and the PAV in $50 \%$ ), males spent $61.2 \%(24.3 \%)$ of their time foraging in the cells that were used by females, and females spent $50.2 \%$ $(8.9 \%)$ of their time foraging in regions used by males (Fig. 5). Juveniles spent $30.9 \%(10.0 \%)$ of their time at sea foraging in the regions used by males and 30.0\% $(16.7 \%)$ in the regions used by females (Fig. 5). Trendlines that depicted the proportion of time that males and females foraged in the regions used by juveniles were relatively short (Fig. 5) because males (14.1\%, [2.9\%]) and females $(7.7 \%,[1.4 \%])$ rarely foraged in the pelagic regions used by juveniles (Figs. 1 \& 5).

The areas used by females and males, which were not used by other age/sex groups, are based on the minimum size of the PAV during $50 \%$ of time at sea (Fig. 6). Most of the grid cells that were used almost exclusively by females were located within $50 \mathrm{~km}$ of the colony, in the arc from east to southeast and from south to southwest (Fig. 6A). Most of the region that 
Table 2. Arctocephalus forsteri. Summary data on parameters that described physical and biological characteristics of the habitats used by 25 female, 21 adult male and 6 juvenile NZ fur seals. Means \pm SD are shown

\begin{tabular}{|c|c|c|c|c|c|c|c|c|c|c|}
\hline \multirow{2}{*}{$\begin{array}{l}\text { Seal } \\
\text { no. }\end{array}$} & \multirow{2}{*}{$\begin{array}{l}\text { Southern } \\
\text { season }\end{array}$} & \multirow{2}{*}{$\begin{array}{c}\text { Seal } \\
\text { sex }\end{array}$} & \multirow{2}{*}{$\begin{array}{l}\text { Age } \\
\text { class }\end{array}$} & \multirow{2}{*}{$\begin{array}{c}\text { Cont shelf, } \\
\text { shelf break } \\
\text { or pelagic }\end{array}$} & \multirow[b]{2}{*}{$\begin{array}{l}\text { Mean } \\
(\mathrm{m})\end{array}$} & \multirow{2}{*}{$\begin{array}{c}\text { Median } \\
(\mathrm{m})\end{array}$} & \multirow{2}{*}{$\begin{array}{l}\text { Bathymetry } \\
\text { Mean gradient } \\
\text { (change in depth }[\mathrm{m}] \\
\text { per horizontal } \mathrm{km} \text { ) }\end{array}$} & \multirow{2}{*}{$\begin{array}{l}\text { Median gradient } \\
\text { direction } \\
\left(^{\circ}\right)\end{array}$} & \multirow{2}{*}{$\begin{array}{l}\text { Mean SST } \\
\left({ }^{\circ} \mathrm{C}\right)\end{array}$} & \multirow{2}{*}{$\begin{array}{c}\text { Mean surface } \\
\text { chl a } \\
\left(\mathrm{mg} \mathrm{m}^{-3}\right)\end{array}$} \\
\hline & & & & & & & & & & \\
\hline 14 & Winter & F & Adult & Shelf & $43.2 \pm 14.0$ & 46.6 & $1 \pm 0$ & 113 & $15.7 \pm 0.3$ & $0.28 \pm 0.02$ \\
\hline 15 & Winter & F & Adult & Shelf & $28.3 \pm 10.5$ & 30.6 & $1 \pm 0$ & 315 & $15.7 \pm 0.2$ & $0.32 \pm 0.01$ \\
\hline 30 & Winter & F & Adult & Shelf & $43.9 \pm 42.6$ & 41.2 & $1 \pm 1$ & 76 & $15.2 \pm 0.3$ & $0.64 \pm 0.20$ \\
\hline 51 & Winter & F & Adult & Shelf & $47.1 \pm 9.0$ & 49.4 & $0 \pm 0$ & 135 & $14.5 \pm 0.8$ & $0.37 \pm 0.03$ \\
\hline 52 & Winter & F & Adult & Shelf & $32.4 \pm 16.2$ & 34.3 & $1 \pm 0$ & 307 & $15.4 \pm 0.2$ & $0.45 \pm 0.04$ \\
\hline 90 & Winter & F & Adult & Shelf & $45.6 \pm 16.5$ & 51.2 & $1 \pm 0$ & 297 & $16.3 \pm 1.2$ & $0.37 \pm 0.06$ \\
\hline 91 & Winter & F & Adult & Shelf & $34.2 \pm 17.9$ & 31.9 & $1 \pm 0$ & 315 & $16.9 \pm 0.4$ & $0.62 \pm 0.04$ \\
\hline 125 & Autumn & F & Adult & Shelf & $55.0 \pm 19.4$ & 65.5 & $1 \pm 0$ & 270 & $17.3 \pm 0.3$ & $0.54 \pm 0.06$ \\
\hline 126 & Autumn & F & Adult & Shelf & $40.0 \pm 15.5$ & 42.2 & $1 \pm 0$ & 326 & $17.3 \pm 0.5$ & $0.37 \pm 0.04$ \\
\hline 138 & Winter & F & Adult & Shelf & $47.5 \pm 16.7$ & 53.2 & $1 \pm 0$ & 288 & $16.9 \pm 0.2$ & $0.44 \pm 0.07$ \\
\hline 156 & Winter & F & Adult & Shelf & $47.3 \pm 20.0$ & 52.0 & $1 \pm 1$ & 315 & $16.6 \pm 0.3$ & $0.59 \pm 0.10$ \\
\hline 161 & Winter & $\mathrm{F}$ & Adult & Shelf & $41.1 \pm 17.6$ & 37.6 & $1 \pm 1$ & 180 & $16.4 \pm 0.2$ & $0.55 \pm 0.07$ \\
\hline 169 & Winter & $\mathrm{F}$ & Adult & Shelf & $36.5 \pm 18.6$ & 29.7 & $2 \pm 3$ & 225 & $16.4 \pm 0.2$ & $0.49 \pm 0.14$ \\
\hline 176 & Winter & $\mathrm{F}$ & Adult & Shelf & $44.7 \pm 18.8$ & 39.3 & $1 \pm 1$ & 166 & $16.4 \pm 0.1$ & $0.54 \pm 0.07$ \\
\hline 181 & Winter & $\mathrm{F}$ & Adult & Shelf & $13.0 \pm 4.2$ & 13.0 & $1 \pm 0$ & 326 & $16.5 \pm 0.2$ & $0.45 \pm 0.12$ \\
\hline 193 & Winter & $\mathrm{F}$ & Adult & Shelf & $41.4 \pm 15.7$ & 38.5 & $1 \pm 0$ & 180 & $16.3 \pm 0.2$ & $0.53 \pm 0.09$ \\
\hline 194 & Winter & $\mathrm{F}$ & Adult & Shelf & $44.8 \pm 20.2$ & 49.4 & $1 \pm 1$ & 63 & $15.5 \pm 0.6$ & $0.60 \pm 0.09$ \\
\hline 235 & Winter & $\mathrm{F}$ & Adult & Shelf & $41.7 \pm 14.3$ & 39.6 & $1 \pm 1$ & 216 & $15.6 \pm 0.4$ & $0.48 \pm 0.12$ \\
\hline 298 & Summer & $\mathrm{F}$ & Adult & Shelf & $18.9 \pm 10.1$ & 18.0 & $1 \pm 1$ & 257 & $17.8 \pm 0.1$ & $0.51 \pm 0.04$ \\
\hline 299 & Summer & $\mathrm{F}$ & Adult & Shelf & $19.8 \pm 5.6$ & 20.0 & $2 \pm 1$ & 165 & $17.7 \pm 0.1$ & $0.48 \pm 0.04$ \\
\hline 120 & Summer & $\mathrm{F}$ & Adult & Shelf & $13.2 \pm 2.5$ & 12.5 & $1 \pm 1$ & 101 & $18.5 \pm 0.0$ & $0.52 \pm 0.02$ \\
\hline 300 & Autumn & $\mathrm{F}$ & Adult & Shelf & $66.7 \pm 54.3$ & 62.2 & $2 \pm 2$ & 51 & $16.7 \pm 0.8$ & $0.51 \pm 0.16$ \\
\hline 312 & Autumn & $\mathrm{F}$ & Adult & Shelf & $58.4 \pm 19.7$ & 59.0 & $2 \pm 2$ & 51 & $16.9 \pm 0.7$ & $0.51 \pm 0.13$ \\
\hline 148 & Winter & M & Adult & Shelf & $49.0 \pm 22.3$ & 46.6 & $1 \pm 1$ & 149 & $16.6 \pm 0.3$ & $0.50 \pm 0.22$ \\
\hline 454 & Summer & M & Adult & Shelf & $20.5 \pm 10.2$ & 18.7 & $1 \pm 0$ & 315 & $19.3 \pm 0.2$ & $0.28 \pm 0.09$ \\
\hline 109 & Autumn & M & Adult & Break & $134.4 \pm 151.6$ & 96.0 & $19 \pm 24$ & 29 & $17.2 \pm 0.4$ & $0.32 \pm 0.14$ \\
\hline 110 & Autumn & M & Adult & Break & $210.0 \pm 475.4$ & 94.3 & $24 \pm 30$ & 42 & $17.3 \pm 0.4$ & $0.32 \pm 0.11$ \\
\hline 149 & Winter & M & Adult & Break & $343.1 \pm 328.14$ & 256.9 & $51 \pm 41$ & 29 & $16.7 \pm 0.3$ & $0.27 \pm 0.04$ \\
\hline 182 & Winter & M & Adult & Break & $238.1 \pm 284.9$ & 90.0 & $38 \pm 47$ & 22 & $16.6 \pm 0.2$ & $0.33 \pm 0.07$ \\
\hline 234 & Winter & M & Adult & Break & $89.9 \pm 45.5$ & 124.0 & $3 \pm 1$ & 25 & $15.4 \pm 0.1$ & $0.22 \pm 0.06$ \\
\hline 270 & Spring & M & Adult & Break & $324.1 \pm 239.4$ & 241.2 & $44 \pm 28$ & 35 & $15.0 \pm 0.3$ & $0.27 \pm 0.04$ \\
\hline 272 & Spring & M & Adult & Break & $221.9 \pm 216.8$ & 132.7 & $38 \pm 35$ & 32 & $15.0 \pm 0.2$ & $0.24 \pm 0.03$ \\
\hline 275 & Spring & M & Adult & Break & $242.6 \pm 186.7$ & 194.1 & $27 \pm 21$ & 27 & $15.0 \pm 0.3$ & $0.27 \pm 0.04$ \\
\hline 283 & Spring & M & Adult & Break & $264.8 \pm 225.1$ & 231.0 & $41 \pm 37$ & 25 & $15.0 \pm 0.4$ & $0.29 \pm 0.05$ \\
\hline 293 & Spring & M & Adult & Break & $680.0 \pm 594.6$ & 561.4 & $42 \pm 38$ & 25 & $15.1 \pm 0.3$ & $0.23 \pm 0.05$ \\
\hline 296 & Spring & M & Adult & Break & $87.8 \pm 43.25$ & 87.6 & $4 \pm 5$ & 45 & $16.0 \pm 1.1$ & $0.50 \pm 0.23$ \\
\hline 297 & Spring & M & Adult & Break & $505.2 \pm 769$ & 141.1 & $25 \pm 28$ & 40 & $15.6 \pm 1.0$ & $0.32 \pm 0.14$ \\
\hline 294 & Autumn & $\mathrm{M}$ & Adult & Break & $160.1 \pm 118.0$ & 137.4 & $21 \pm 18$ & 22 & $16.9 \pm 0.2$ & $0.20 \pm 0.03$ \\
\hline 282 & Autumn & M & Adult & Break & $265.6 \pm 560.8$ & 112.4 & $23 \pm 24$ & 36 & $16.3 \pm 0.6$ & $0.26 \pm 0.09$ \\
\hline 352 & Winter & M & Adult & Break & $172.7 \pm 160.3$ & 114.3 & $22 \pm 21$ & 21 & $15.5 \pm 0.3$ & $0.27 \pm 0.06$ \\
\hline 382 & Winter & M & Adult & Break & $214.4 \pm 142.0$ & 194.1 & $31 \pm 17$ & 11 & $15.3 \pm 0.4$ & $0.23 \pm 0.05$ \\
\hline 281 & Winter & M & Adult & Break & $769.2 \pm 663.5$ & 612.3 & $32 \pm 22$ & 26 & $14.8 \pm 0.7$ & $0.22 \pm 0.04$ \\
\hline 285 & Summer & M & Adult & Break & $174.1 \pm 318.0$ & 108.7 & $24 \pm 18$ & 31 & $17.6 \pm 0.8$ & $0.20 \pm 0.06$ \\
\hline 29 & Winter & $\mathrm{F}$ & Adult & Pelagic & $1707.7 \pm 1871.7$ & 1138.8 & $57 \pm 68$ & 52 & $14.7 \pm 0.9$ & $0.24 \pm 0.06$ \\
\hline 132 & Winter & $\mathrm{F}$ & Adult & Pelagic & $3757.0 \pm 2264.7$ & 5317.2 & $22 \pm 45$ & 27 & $15.8 \pm 0.9$ & $0.27 \pm 0.06$ \\
\hline 453 & Summer & M & Adult & Pelagic & $4645.7 \pm 1392.9$ & 5076.3 & $11 \pm 26$ & 125 & $17.7 \pm 0.5$ & $0.14 \pm 0.04$ \\
\hline 305 & Autumn & $\mathrm{M}$ & Juvenile & Pelagic & $4369.7 \pm 780.1$ & 4498.0 & $13 \pm 26$ & 172 & $13.3 \pm 2.3$ & $0.20 \pm 0.05$ \\
\hline 308 & Autumn & $\mathrm{M}$ & Juvenile & Pelagic & $4649.0 \pm 1065.8$ & 4999.0 & $18 \pm 40$ & 212 & $14.5 \pm 1.0$ & $0.27 \pm 0.08$ \\
\hline 309 & Autumn & $\mathrm{F}$ & Juvenile & Pelagic & $4475.2 \pm 883.4$ & 4518.1 & $22 \pm 35$ & 135 & $13.6 \pm 2.1$ & $0.22 \pm 0.08$ \\
\hline 450 & Summer & $\mathrm{F}$ & Juvenile & Pelagic & $4457.2 \pm 1267.1$ & 4767.4 & $11 \pm 13$ & 90 & $15.1 \pm 1.9$ & $0.33 \pm 0.13$ \\
\hline 451 & Summer & $\mathrm{M}$ & Juvenile & Pelagic & $2505.2 \pm 1937.4$ & 2564.5 & $47 \pm 49$ & 39 & $15.3 \pm 0.7$ & $0.22 \pm 0.08$ \\
\hline 452 & Summer & $\mathrm{F}$ & Juvenile & Pelagic & $3764.2 \pm 1811.4$ & 4639.6 & $18 \pm 25$ & 49 & $14.4 \pm 0.7$ & $0.49 \pm 0.87$ \\
\hline \multicolumn{2}{|c|}{ Shelf females } & & & & $39.3 \pm 13.6$ & 39.9 & $1 \pm 1$ & 216 & $16.5 \pm 0.93$ & $0.49 \pm 0.09$ \\
\hline \multicolumn{2}{|c|}{ Pelagic females } & & & & $2732.4 \pm 1449.1$ & 3228.0 & $40 \pm 16$ & 40 & $15.3 \pm 0.78$ & $0.26 \pm 0.02$ \\
\hline Shelf & males & & & & $34.8 \pm 20.2$ & 32.7 & $1 \pm 1$ & 232 & $18.0 \pm 1.91$ & $0.39 \pm 0.16$ \\
\hline Shelf & break males & & & & $283.2 \pm 188.4$ & 196.1 & $28 \pm 12$ & 28 & $15.9 \pm 0.93$ & $0.28 \pm 0.07$ \\
\hline Pelag & ic male & & & & $4645.7 \pm 1392.9$ & 5076.3 & $11 \pm 26$ & 125 & $17.7 \pm 0.5$ & $0.14 \pm 0.04$ \\
\hline Juve & iles (all) & & & & $4036.8 \pm 809.3$ & 4578.9 & $22 \pm 13$ & 113 & $14.4 \pm 0.8$ & $0.29 \pm 0.11$ \\
\hline Juve & ile females & & & & $4232.2 \pm 405.4$ & 4639.6 & $17 \pm 6$ & 90 & $14.4 \pm 0.8$ & $0.35 \pm 0.14$ \\
\hline Juve & ile males & & & & $3841.3 \pm 1167.2$ & 4498.0 & $26 \pm 14$ & 172 & $14.4 \pm 1.0$ & $0.23 \pm 0.04$ \\
\hline
\end{tabular}




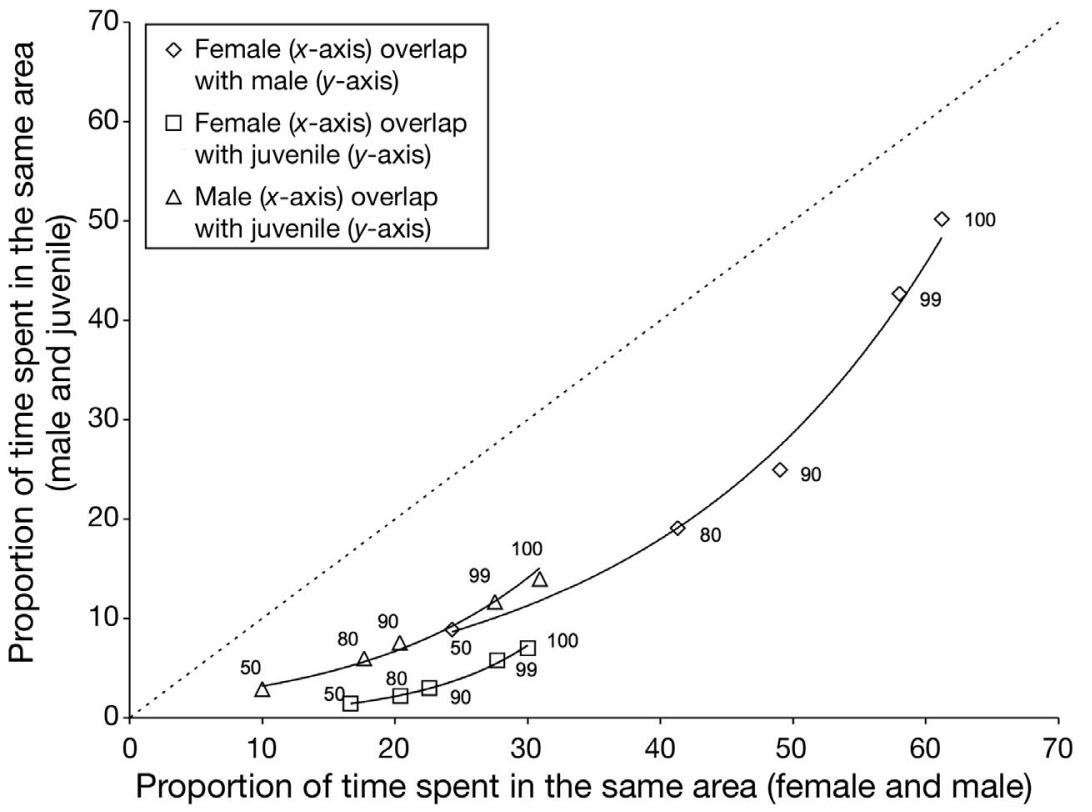

Fig. 5. Arctocephalus forsteri. Relationship between proportion of time spent in the same $25 \mathrm{~km}^{2}$ cells by different age/sex groups, depicting overlap based on minimum size of the potential area visited during the entire trip (i.e. $100 \%$ of cells visited) and overlap based on minimum size of the potential area visited during 99, 90, 80 and $50 \%$ of time spent foraging for each age/sex group. Power curves are plotted to indicate relationship between amount of time that each age/sex group spent foraging in areas of overlap

was used exclusively by males was bounded to the north by the foraging grounds utilised by females (Fig. 1A) and to the south by the $1000 \mathrm{~m}$ depth contour (Fig. 6B). The region that was used almost exclusively by males extended along approximately $130 \mathrm{~km}$ of the shelf break (Fig. 6B). The areas used almost exclusively by juveniles are not depicted because adult foraging grounds overlapped to such a small extent with juvenile foraging grounds (Figs. 1 \& 5).

\section{DISCUSSION}

Our data support the hypothesis that lactating female, adult male and juvenile NZ fur seals typically forage in spatially separated habitats (Fig. 1). Several studies have demonstrated how different demographic groups use resources in different ways, broadening the overall niche and reducing intra-specific competition. For example, inter-sexual differences have been related to bill dimorphism in birds (e.g. Radford \& Du Plessis 2003), gape size in sea-snakes (e.g. Shine et al. 2002), costs and benefits associated with storing and transporting body fat and ontogenetic niche shifts in phocid seals (Beck et al. 2003, Field et al. 2005) and the diet and dive behaviour of fur seals (Robson et al. 2004, Sterling \& Ream 2004, Page et al. 2005a,b).

\section{Lactating female foraging behaviour}

Previous studies indicate that animals forage in regions where they can satisfy their metabolic requirements in a biologically-significant period (Lindstedt et al. 1986, Thompson et al. 1998, Field et al. 2005). Although lactating females are intermediate in size to adult males and juveniles, the females in this study typically conducted the shortestduration trips (Table 1), highlighting the constraints imposed by their dependent pups. We found that during summer, when their pups were young and small, lactating females conducted brief trips and foraged in relatively shallow waters closer to the colony, nursing their pups in brief but regular bouts. In our study and in New Zealand, lactating females performed their longest duration trips in autumn and winter, when their pups were larger and therefore had greater fasting capacities (Harcourt et al. 1995, 2002, Mattlin et al. 1998).

Two hypotheses could explain our finding that female foraging-trip duration is positively related to the distance they travelled. Firstly, the positive relationship indicates that a pup's fasting ability influences the distance its mother can travel, as has been suggested in other studies (Boyd 1999, Bonadonna et al. 2000, Harcourt et al. 2002, Robson et al. 2004). Secondly, these differences in trip duration may represent seasonal differences in prey availability. Although we did not measure prey abundance, differences in surface chl a concentrations are thought to relate to both secondary and tertiary productivity in this region (Ward et al. 2004). The regions used by lactating female and adult male NZ fur seals lie on the northern edge of the Flinders Current, which flows from east to west along the outer shelf break (Middleton \& Cirano 2002). During summer and autumn, southeasterly winds drive pulses of coastal upwelling, which draw cool (13 to $\left.15^{\circ} \mathrm{C}\right)$, nutrient-rich water from the Flinders Current onto the shelf and result in enhanced chlorophyll concentrations and zooplankton biomass across the continental shelf and shelf break (Lewis 1981, Schahinger 1987, Ward et al. 2004). In this region, coastal upwelling results in increased secondary and tertiary productivity compared with other seasons (Ward et al. 2004). We found that females used regions with lower surface chl a concentrations in summer, indicating that either the upwelling had not commenced or that females could not (or did not need to) travel to regions 

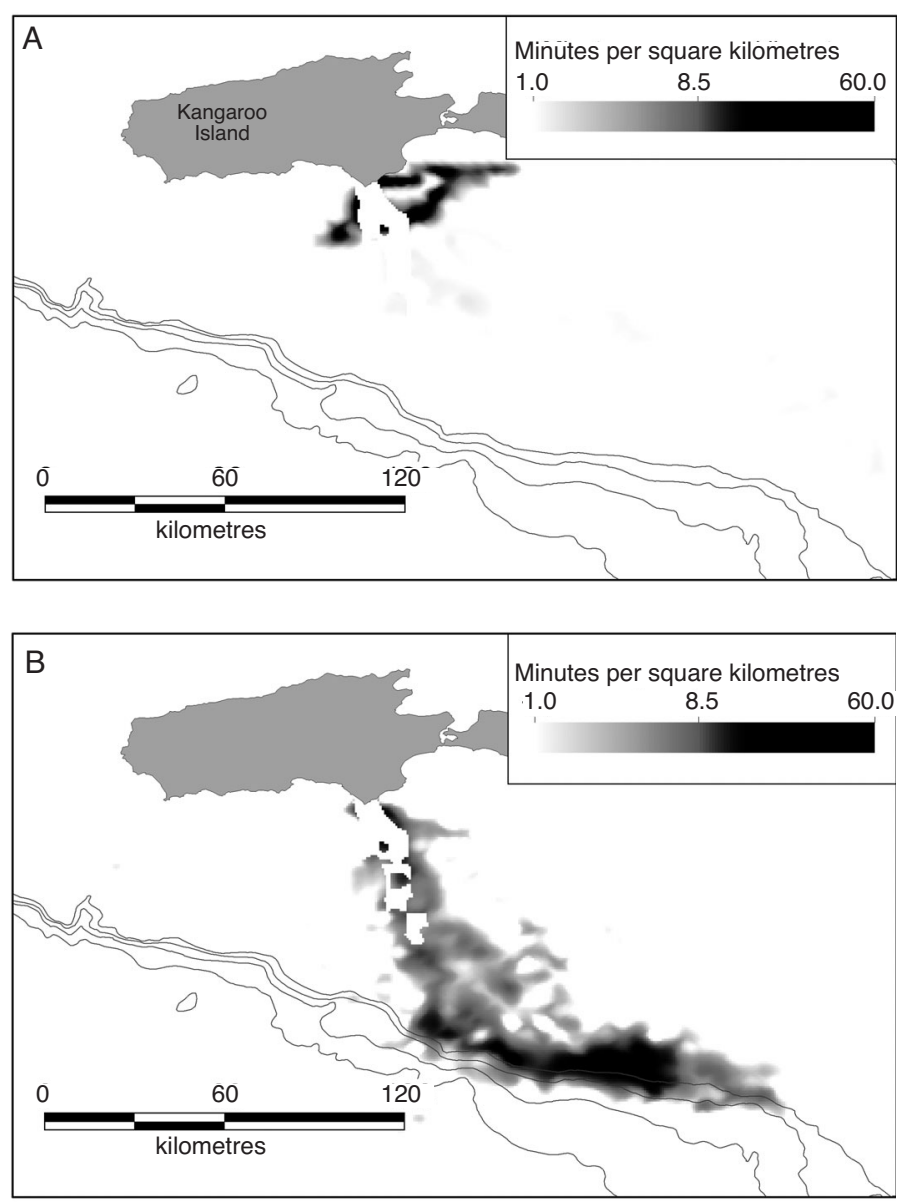

Fig. 6. Arctocephalus forsteri. Spatial distribution of $25 \mathrm{~km}^{2}$ cells, which were used by only 1 age/sex group, based on minimum size of the potential area visited in $50 \%$ of time spent at sea for each age/sex group. For areas used by only 1 age/sex group, time spent in each $25 \mathrm{~km}^{2}$ cell is plotted for (A) females and (B) adult males. 200, 500, 1000 and $2000 \mathrm{~m}$ depth contours shown

with the highest chl a concentrations, if they were present. Alternately, our index of surface chl a concentration may have underestimated the total chl a concentration in these regions if the upwelled water did not reach the surface.

In New Zealand, lactating NZ fur seals were also recorded making brief trips in summer, indicating that enough prey was available close to the colony to support their small pups (Harcourt et al. 1995, Harcourt et al. 2002). During autumn and winter, we found that female NZ fur seals foraged further from the colony and that during autumn females were utilising regions with enhanced productivity. Although females may have been preferentially utilising regions with relatively high chl a concentrations, our results do not include data from regions that were not used by females. As a result, our study focuses on seasonal differences and differences in the regions used by lactating females, adult males and juveniles.

In winter, 2 females traversed continental shelf and shelf break waters to forage in pelagic waters (Fig. 1A). The distances these females travelled were among the highest we recorded (Table 1). Given that SST and surface chlorophyll concentrations over the continental shelf decreased between autumn and winter, it is likely that tertiary productivity also decreased, compelling some females to invest more time traveling in order to utilise pelagic waters. Interestingly, the diving behaviour of lactating female NZ fur seals and Australian sea lions from Seal Bay $(20 \mathrm{~km}$ northwest of Cape Gantheaume) also indicates that prey over the continental shelf is harder to utilise in winter (Costa \& Gales 2003, Page et al. 2005a). Both lactating NZ fur seals and Australian sea lions dived deeper during winter, suggesting that prey were located closer to the benthos or that seals foraged in different regions (Costa \& Gales 2003, Page et al. 2005a). Based on similar findings of dive depth and distance travelled, Harcourt et al. (2002) also suggested that foraging conditions become more difficult for female NZ fur seals in colder months compared to summer.

Female NZ fur seals that travel to pelagic habitats (distant) are thought to expend more energy than those feeding closer to the colony (Arnould et al. 1996). The lactating females may be compensated for the additional time and energy they expended commuting to pelagic foraging grounds if they can procure more energy per unit time in pelagic regions compared to the demersal habitats of the continental shelf. This may be because prey in pelagic waters are either more abundant or energy-dense. Some fur seal foraging behaviour studies support this idea, because females that invest more time traveling often exploit prey in shallower depths compared with females on shorter trips (e.g. Boyd et al. 1991, Arnould et al. 1996, Page et al. 2005a). Seals undertaking longer trips may also be compensated for the additional energy they expend if the prey they consume contain more energy than those found locally.

Central-place foragers such as lactating fur seals utilise reliable sources of prey in order to regularly provision their dependent young. Previous studies have shown that some lactating fur seals utilise regions with relatively high surface chl a concentrations if they are within their foraging range (e.g. Georges et al. 2000, Guinet et al. 2001). The continental shelf regions used by the lactating females in this study had similar SST, but the surface waters contained almost twice the density of chl a as the shelf break regions used by males (Table 1, Fig. 3). It is possible that lactating NZ fur seals utilise these regions because they contain a temporally- and spatially-reliable source of prey, 
which are accessible in relatively shallow depths. By utilising reliable foraging habitats, females may minimise their foraging trip durations and maximise their foraging success, which is how they maximise milk delivery rates to their pups.

\section{Adult male foraging behaviour}

Based on the larger body size and greater energy requirements of male fur seals, males may either utilise a different niche in the same regions as lactating females and/or may utilise spatially separated regions. Because we showed that males and females use spatially separated habitats, we expect that males can procure more energy per unit time in the deeper waters over the shelf break compared to waters over the continental shelf. Accordingly, we expect the shelf break habitat would contain the highest densities of their preferred prey. Our finding that surface waters over the shelf break habitat comprise a relatively low chl a concentration, compared to the continental shelf, does not support this expectation. However, it is possible that the chl a concentration index does not represent total chl a concentration in this region, because upwelled waters may not reach the surface often over the deeper shelf break habitat. Alternately, chl a concentration and prey aggregations may have been spatially and temporally separated during the study.

Little is known about the behaviour of fur seal prey in this region, but there is indirect evidence that suggests the shelf break does support relatively high densities of fishes and cephalopods. Firstly, data from research trawls in the region indicated that small pelagic fishes were concentrated over shelf break waters compared with continental shelf waters (Shuntov 1969). Secondly, commercial trawl data from the South East Trawl Fishery indicates that this region supports a significant biomass of fishes and cephalopods (Australian Fisheries Management Authority 2001). The spatial distribution of fishing effort indicates that trawlers exclusively operate over shelf break areas, but not over continental shelf or pelagic waters (Australian Fisheries Management Authority 2001). In the regions used intensely by male fur seals and the fishery, trawl effort is between 3 and $24 \mathrm{~km}$ trawled $\mathrm{km}^{-2}$ and fishery catch is between 0.5 and $2.0 \mathrm{t} \mathrm{km}^{-2}$ each year (Australian Fisheries Management Authority 2001). Although we cannot be sure that male NZ fur seals utilise the shelf break because it supports a higher density of marine resources, these observations suggest that relatively high densities of fishes and cephalopods occur in this region.

Given that intra-sexual competition favours larger body size in male fur seals, their central-place foraging tendency seems unusual. Page et al. (2005a) discussed 3 possible reasons for this counter-intuitive behaviour: (1) the benefits of displaying to females and rivals outside the breeding season (Troy 1997), (2) delaying fat accumulation until immediately prior to the breeding season (Beck et al. 2003) and (3) predator avoidance. Similarly unconstrained harbour seals Phoca vitulina and southern elephant seals Mirounga leonina exhibit relationships between trip duration and (1) body size and (2) age, respectively (Thompson et al. 1998, Field et al. 2005), but this has not been demonstrated for male otariids (Sterling \& Ream 2004, Page et al. 2005a). Although we found that the distances travelled by males were positively related to trip duration, this relationship offers little insight into factors that affect male fur seal foraging trip duration.

\section{Juvenile foraging behaviour}

Given the relationship between the body size of seals and their diving capacity (Kooyman 1989), juvenile fur seals are most likely restricted to nocturnal foraging in near-surface waters. The diving behaviour of adult male and female NZ fur seals suggests that an ability to efficiently exploit benthic prey is necessary to utilise continental shelf and shelf break habitats (Page et al. 2005a). Although juveniles undoubtedly forage when they encounter suitable prey patches over the continental shelf or shelf break, juvenile body size limits their available depth range and they would be forced to continue into pelagic waters if prey were too big or at depth. Median dive depth and duration for lactating females that foraged over the continental shelf was $57.5 \mathrm{~m}$ and $2.9 \mathrm{~min}$, compared with $19.0 \mathrm{~m}$ and $2.6 \mathrm{~min}$ for females that utilised pelagic habitats, suggesting that prey occur at shallower depths in pelagic waters (Page et al. 2005a). In pelagic waters, juveniles would most likely be able to utilize similar prey to lactating females because, as pups, NZ fur seals have been recorded diving to $44 \mathrm{~m}$ for up to 3.3 min (Baylis et al. 2005).

Although we did not find inter-sexual differences in the behaviour of juvenile males and females, this may be an artefact of our small sample sizes (Table 1). In southern elephant seals, juvenile females make longer duration foraging trips than juvenile males, but otherwise their foraging behaviour is similar (Field et al. 2005). Field et al. (2005) attributed these similarities to the lack of sexual dimorphism during the juvenile years. Similarly, in NZ fur seals, sexual dimorphism becomes apparent after 5 years of age, when annual growth rates first differ significantly (J. McKenzie unpubl. data). Although the trigger for the transition from juvenile to adult foraging behaviour is not known, 
it is possible that changes in foraging behaviour occur when annual growth rates diverge and sexual dimorphism becomes apparent (males) or following parturition (females).

Juvenile NZ fur seals typically foraged in association with the subtropical front, which is characterised by relatively high chl a concentrations and low SST $\left(\sim 14^{\circ} \mathrm{C}\right)$ (e.g. Pakhomov et al. 1994). Fishes and cephalopods that are associated with the subtropical front typically perform vertical migrations to spend the day at great depths, but return to near-surface waters at night to feed on plankton (Pakhomov et al. 1994). New Zealand fur seals that use pelagic waters are thought to target lanternfishes at night, which are approximately 8 to $10 \mathrm{~cm}$ long and 7 to $10 \mathrm{~g}$ (Page et al. $2005 a, b)$. In contrast, when foraging over continental shelf and shelf break habitats, adult female and male NZ fur seals utilise fishes and cephalopods that are approximately 15 times heavier than the lanternfishes they utilise in pelagic waters (Page et al. 2005b). In addition to their reduced diving capacity, small seals may not be able to capture, kill and consume large prey underwater, which may explain why juveniles exploit the small prey that occur in pelagic habitats. There are no comparative data on the energy content or behaviour of fur seal prey species from continental shelf waters or pelagic waters, so we cannot determine if juvenile NZ fur seals and some adult NZ fur seals travel to pelagic waters because prey are more energy rich or easier to access.

The increased need to haul-out during the annual moult may be the reason for the shorter duration foraging trips conducted by juveniles during summer. In autumn, juveniles dispersed more widely in search of prey, possibly reflecting the reduced availability of their prey in nearshore waters. Although juvenile NZ fur seal foraging behaviour was not recorded in winter and spring, the similarities in their diet suggest that juveniles utilise pelagic waters throughout the year (Page et al. 2005b).

\section{Habitat separation among male, female and juvenile NZ fur seals}

The degree of habitat separation that we observed between female, male and juvenile NZ fur seals is intriguing, because most individuals conducted relatively brief trips (Table 1) and returned to colonies on Kangaroo Island, generating the potential for resource competition in nearby waters. However, the areas of spatial overlap were relatively small and were typically located within $50 \mathrm{~km}$ of Cape Gantheaume, a region that was utilised extensively by lactating females (Figs. 1A \& 6A) but less so by adult males and juveniles (Figs. 1B,C, 5 \& 6B). The foraging habitats used by lactating females were typically closer to the colony than those used by adult males and juveniles (Fig. 1), similar to the findings of previous studies on otariids (Sterling \& Ream 2004, Ream et al. 2005, Page et al. 2005a and references therein). The degree of spatial overlap in male and juvenile foraging habitats was also minimal (Figs. 1B,C, 5 \& 6B). Adult males typically foraged along the shelf break, and juveniles foraged further south in pelagic waters (Fig. 1B,C). Furthermore, the closer that seals were to the colony, the faster they travelled, which suggests that when seals were in the areas of greatest spatial overlap, they were typically commuting to their preferred foraging grounds (Fig. 1). Dive records also indicate that adult male and lactating female NZ fur seals spend relatively little time foraging in waters adjacent to the colony, because few dives were recorded within 3 to $5 \mathrm{~h}$ of their departure/arrival (Page et al. 2005a). Rapid traversing of nearshore waters is also evident among chick-rearing seabirds (e.g. Gremillet et al. 2004), which implies that these colonial breeding animals cannot rely on nearshore resources, in accordance with the theory of localised depletion (Ashmole 1963, Birt et al. 1987).

We showed that adult male and lactating female NZ fur seals used adjoining habitats throughout the year. Concurrent dietary studies indicate that about twothirds of their prey comprises a similar biomass of the same species (Page et al. 2005b). Although males consume heavier prey than females, there is also considerable overlap in prey mass. Males typically dive deeper than females, but in some months (e.g. winter) the mean dive depth of females $(47.8 \pm 4.0 \mathrm{~m})$ and males $(51.6 \pm 8.5 \mathrm{~m})$ did not differ significantly, suggesting that prey over the shelf break would sometimes be within the diving capacity of females (Page et al. 2005a). It is worth speculating about why lactating females do not use the shelf break habitat, because in places it is closer to Cape Gantheaume (e.g. $70 \mathrm{~km}$ due south) than the average maximum distance females travelled $(108 \pm 74 \mathrm{~km})$ (Table 1$)$. This spatial separation could be explained by inter-sexual differences in the physiological diving capacity of adult males and females. Dive behaviour studies indicate that lactating female and adult male NZ fur seals utilise both pelagic and benthic habitats, but males perform deeper and longer duration dives, which typically occur over the shelf break (Page et al. 2005a). The continental shelf habitat has a relatively constant depth (Table 2), which suggests that prey would remain within the dive capacity of lactating females over the entire shelf, possibly making this a more reliable habitat for females. Females may avoid spending time over the shelf break for the same reason that juveniles are thought to avoid 
both continental shelf and shelf break waters: prey can be too deep. The necessity to perform deep dives to utilise demersal or benthic prey (if prey are not located near the surface) may determine whether seals can use continental shelf or shelf break habitats.

\section{CONCLUSIONS}

This study provides a demonstration of reduced intra-specific competition among lactating female, adult male and juvenile NZ fur seals. Pup-rearing constraints on females and differences in body size among the age/sex groups are most likely responsible for the observed differences in the way lactating females, males and juveniles utilise resources. Larger individuals have a capacity to dive deeper and spend longer underwater than smaller individuals, which opens up different niches and a wider assortment of potential prey for larger individuals. It seems likely that smaller seals are restricted to foraging in pelagic regions where prey migrate into near-surface waters at night. In contrast, prey over the continental shelf and shelf break do not seem to reliably migrate off the seafloor. Rather than risking periods of inefficient foraging over the shelf break, females utilise shallower continental shelf habitats, which have relatively high surface chl a concentrations. We suggest that males use shelf break habitats because they may contain a relative abundance of larger, more energy-dense prey, which lactating females cannot efficiently exploit. Direct measurements of the distribution and abundance of fur seal prey in these habitats would increase our understanding of what underpins the spatial separation of foraging habitats among fur seals.

Acknowledgements. We thank the enthusiastic researchers who worked with us on Kangaroo Island, particularly Adam Morrissey, Bec McIntosh and Luke Einoder. We thank Anthony Maguire, Dave Dowie and other National Parks staff who helped tremendously with field logistics. Insightful comments from Mark Hindell, Iain Staniland, Rob Harcourt, Tom Gelatt and 3 anonymous reviewers greatly improved this manuscript. This project was supported by the Sea World Rescue and Research Foundation, the South Australian Department for Environment and Heritage Wildlife Conservation Fund, Australian Geographic and PADI Project AWARE. B.P. received the CSIRO Marine Research scholarship and an Australian Postgraduate Award to conduct this project.

\section{LITERATURE CITED}

Andersson M (1994) Sexual selection. Princeton University Press, Princeton, NJ

Arnould JPY, Boyd IL, Speakman JR (1996) The relationship between foraging behaviour and energy expenditure in Antarctic fur seals. J Zool 239:769-782
Ashmole NP (1963) The regulation of numbers of tropical oceanic birds. Ibis 103:458-473

Ashmole NP (1968) Body size, prey size and ecological segregation in 5 sympatric tropical terns (Aves: Laridae). Syst Zool 17:292-304

Australian Fisheries Management Authority (2001) Bycatch action plan: south east trawl fishery. Background paper. Australian Fisheries Management Authority, Canberra

Baylis AMM, Page B, Peters $\mathrm{K}$, McIntosh R, McKenzie J, Goldsworthy SD (2005) The ontogeny of dive behaviour in New Zealand fur seal pups (Arctocephalus forsteri). Can J Zool 83:1149-1161

Beals EW (1984) Bray Curtis ordination: an effective strategy for analysis of multivariate ecological data. Adv Ecol Res 14:1-55

Beck CA, Bowen WD, McMillan JI, Iverson SJ (2003) Sex differences in the diving behaviour of a size-dimorphic capital breeder: the grey seal. Anim Behav 66:777-789

Birt VL, Birt TP, Goulet D, Cairns DK, Montevecchi WA (1987) Ashmole's halo: direct evidence for prey depletion by a seabird. Mar Ecol Prog Ser 40:205-208

Bonadonna F, Lea MA, Guinet C (2000) Foraging routes of Antarctic fur seals (Arctocephalus gazella) investigated by the concurrent use of satellite tracking and time depth recorders. Polar Biol 23:149-159

Boyd IL (1999) Foraging and provisioning in Antarctic fur seals: interannual variability in time-energy budgets. Behav Ecol 10:198-208

Boyd IL, Lunn NJ, Barton T (1991) Time budgets and foraging characteristics of lactating Antarctic fur seals. J Anim Ecol 60:577-592

Boyd IL, Staniland IJ, Martin AR (2002) Distribution of foraging by Antarctic fur seals. Mar Ecol Prog Ser 242: 285-294

Brown CR, Brown MB, Ives AR (1992) Nest placement relative to food and its influence on the evolution of avian coloniality. Am Nat 139:205-217

Costa DP, Gales NJ (2003) Energetics of a benthic diver: seasonal foraging ecology of the Australian sea lion, Neophoca cinerea. Ecol Monogr 73:27-43

Crowder LB (1986) Ecological and morphological shifts in Lake Michigan fishes: glimpses of the ghost of competition past. Environ Biol Fish 16:147-157

Field IC, Bradshaw CJA, Burton HR, Sumner MD, Hindell MA (2005) Resource partitioning through oceanographic segregation of foraging juvenile southern elephant seals (Mirounga leonina). Oecologia 142:127-135

Gales NJ, Cheal AJ (1992) Estimating diet composition of the Australian sea lion Neophoca cinerea from scat analysis: an unreliable technique. Wildl Res 19:447-456

Georges JY, Bonadonna F, Guinet C (2000) Foraging habitat and diving activity of lactating subantarctic fur seals in relation to sea surface temperature at Amsterdam Island. Mar Ecol Prog Ser 196:291-304

Goldsworthy SD, Bulman C, He X, Larcombe J, Littnan C (2003) Trophic interactions between marine mammals and Australian fisheries: an ecosystem approach. In: Gales N, Hindell M, Kirkwood R (eds) Marine mammals and humans: towards a sustainable balance. CSIRO Publishing, Melbourne, p 62-99

Gremillet D, Dell'Omo G, Ryan PG, Peters G, Ropert-Coudert Y, Weeks SJ (2004) Offshore diplomacy, or how seabirds mitigate intra-specific competition: a case study based on GPS tracking of Cape gannets from neighbouring colonies. Mar Ecol Prog Ser 268:265-279

Guinet C, Dubroca L, Lea MA, Goldsworthy S, Cherel Y, Duhamel G, Bonadonna F, Donnay JP (2001) Spatial distri- 
bution of foraging in female Antarctic fur seals Arctocephalus gazella in relation to oceanographic variables: a scale dependent approach using geographic information systems. Mar Ecol Prog Ser 219:251-264

Harcourt RG, Schulman AM, Davis LS, Trillmich F (1995) Summer foraging by lactating female New Zealand fur seals (Arctocephalus forsteri) off Otago Peninsula, New Zealand. Can J Zool 73:678-690

Harcourt RD, Bradshaw CJA, Dickson K, Davis LS (2002) Foraging ecology of a generalist predator, the female New Zealand fur seal. Mar Ecol Prog Ser 227:11-24

Hulsman K (1987) Resource partitioning among sympatric species of tern. Ardea 75:255-262

Hunt GL, Eppley ZA, Schneider DC (1986) Reproductive performance of seabirds: the importance of population and colony size. Auk 103:306-317

Kooyman GL (1989) Diverse divers: physiology and behaviour. Springer Verlag, Berlin

Lewis RK (1981) Seasonal upwelling along the south eastern coastline of South Australia. Aust J Mar Freshw Res 32: 843-854

Lindstedt SL, Miller BJ, Buskirk SW (1986) Home range, time, and body size in mammals. Ecology 67:827-840

Loughlin TR, Ingraham WJ Jr, Baba N, Robson BW (1999) Use of a surface-current model and satellite telemetry to assess marine mammal movements in the Bering Sea. In: Loughlin TR, Ohtani K (eds) Dynamics of the Bering Sea. University of Alaska Sea Grant, Fairbanks, AK, p 615-630

Mattlin RH, Gales NJ, Costa DP (1998) Seasonal dive behaviour of lactating New Zealand fur seals (Arctocephalus forsteri). Can J Zool 76:350-360

McConnell BJ, Chambers C, Nicholas KS, Fedak MA (1992) Satellite tracking of grey seals (Halichoerus grypus). J Zool 226:271-282

Middleton JF, Cirano M (2002) A northern boundary current along Australia's southern shelves: the Flinders Current. J Geophys Res C 107:3129-3143

Orians GH, Pearson NE (1979) On the theory of central place foraging. In: Horn DJ, Stairs BR, Mitchell RD (eds) Analysis of Ecological Systems. Ohio State University Press, Columbus, OH, p 155-177

Page B, McKenzie J, Goldsworthy SD (2005a) Inter-sexual differences in New Zealand fur seal diving behaviour. Mar Ecol Prog Ser 304:249-264

Page B, McKenzie J, Goldsworthy SD (2005b) Dietary resource partitioning among sympatric New Zealand and Australian fur seals. Mar Ecol Prog Ser 293:283-302

Pakhomov EA, Perissinotto R, McQuaid CD (1994) Comparative structure of the macrozooplankton/micronekton com-

Editorial responsibility: Howard I. Browman (Associate Editor-in-Chief), Storebø, Norway munities of the Subtropical and Antarctic Polar Fronts. Mar Ecol Prog Ser 111:155-169

Radford AN, Du Plessis MA (2003) Bill dimorphism and foraging niche partitioning in the green woodhoopoe. J Anim Ecol 72:258-269

R Development Core Team (2004) R: A language and environment for statistical computing. R Foundation for Statistical Computing, Vienna

Ream RR, Sterling JT, Loughlin TR (2005) Oceanographic features related to northern fur seal migratory movements. Deep-Sea Res II 52:823-843

Robson BW, Goebel ME, Baker JD, Ream RR, Loughlin TR, Francis RC, Antonelis GA, Costa DP (2004) Separation of foraging habitat among breeding sites of a colonial marine predator, the northern fur seal (Callorhinus ursinus). Can J Zool 82:20-29

Schahinger RB (1987) Structure of coastal upwelling events observed off the south-east coast of South Australia during February 1983-April 1984. Aust J Mar Freshw Res 38: $439-459$

Schiffman S, Reynolds ML, Young FW (1981) Introduction to multidimensional scaling. Academic Press, New York

Shine R, Reed RN, Shetty S, Cogger HG (2002) Relationship between sexual dimorphism and niche partitioning within a clade of sea snakes (Laticaudinae). Oecologia 133:45-53

Shuntov VP (1969) Some features of the ecology of pelagic fishes in the Great Australian Bight. Probl Ichthyol 9: 801-809

Sterling JT, Ream RR (2004) At-sea behaviour of juvenile male northern fur seals (Callorhinus ursinus). Can J Zool 82:1621-1637

Stewart REA, Stewart BE, Stirling I, Street E (1996) Counts of growth layer groups in cementum and dentine in ringed seals (Phoca hispida). Mar Mamm Sci 12:383-401

Thompson PM, Mackay A, Tollit DJ, Enderby S, Hammond PS (1998) The influence of body size and sex on the foraging characteristics of harbour seal foraging trips. Can J Zool 76:1044-1053

Troy SK (1997) Territorial behaviour and mating success in male New Zealand fur seals, Arctocephalus forsteri. PhD thesis, University of Melbourne

Ward TM, McLeay LJ, Dimmlich WF, Rogers PJ, McClatchie S, Matthews R, Kampf J, Van Ruth P (2004) Pelagic ecology of a northern boundary current system. In: Ward TM, Goldsworthy SD, Page B (eds) Trophodynamics of the GAB: assessing the need for an ecological allocation in the SA pilchard fishery. Fisheries Research and Development Corporation and South Australian Research and Development Institute, Adelaide, p 28-47

Submitted: December 13, 2005; Accepted: March 12, 2006 Proofs received from author(s): September 15, 2006 